Universidad

:\% de Alcalá

\title{
BIBLIOTECA
}

Document downloaded from the institutional repository of the University of Alcala: https://ebuah.uah.es/dspace/

This is a postprint version of the following published document:

Caballo, J. et al., 2013. Reactivity with electrophiles of imido groups supported on trinuclear titanium systems. Inorganic chemistry, 52(19), pp.11519-11529.

Available at https://doi.org/10.1021/ic4018294

(C) 2013 American Chemical Society.

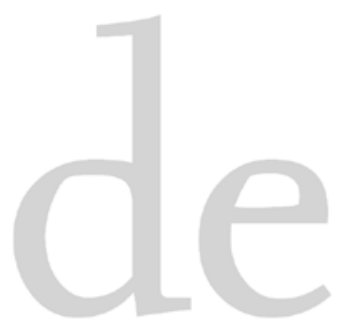

(Article begins on next page)

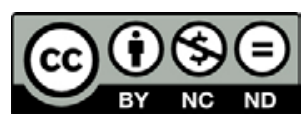

This work is licensed under a

Creative Commons Attribution-NonCommercial-NoDerivatives

4.0 International License. 


\section{Reactivity with Electrophiles of Imido Groups Supported on Trinuclear Titanium Systems}

Jorge Caballo, Mariano González-Moreiras, Miguel Mena, Adrián Pérez-Redondo, and Carlos Yélamos*

Departamento de Química Orgánica y Química Inorgánica, Universidad de Alcalá, 28871 Alcalá de Henares-Madrid (Spain). FAX: (+34) 91-8854683. E-mail: $\underline{\text { carlos.yelamos@uah.es }}$

\section{Synopsis:}

The electrophilic attack of ROTf $(\mathrm{R}=\mathrm{H}, \mathrm{Me})$ on $\left[\left\{\operatorname{Ti}\left(\eta^{5}-\mathrm{C}_{5} \mathrm{Me}_{5}\right)(\mu-\mathrm{NH})\right\}_{3}\left(\mu_{3}-\mathrm{N}\right)\right](\mathbf{1})$ occurs at one $\mathrm{NH}$ imido ligand to give $\left[\mathrm{Ti}_{3}\left(\eta^{5}-\mathrm{C}_{5} \mathrm{Me}_{5}\right)_{3}\left(\mu_{3}-\mathrm{N}\right)(\mu-\mathrm{NH})_{2}(\mu-\mathrm{NHR})(\mathrm{OTf})\right]$ derivatives which undergo rearrangement reactions involving triflato-assisted proton exchange between amido NHR and imido NH ligands. The larger trimethylsilyl fragment of $\mathrm{Me}_{3} \mathrm{SiOTf}$ attacks the same nitrogen of 1 but produces a complex $\left[\mathrm{Ti}_{3}\left(\eta^{5}-\mathrm{C}_{5} \mathrm{Me}_{5}\right)_{3}\left(\mu_{3}-\mathrm{N}\right)(\mu-\right.$ $\left.\mathrm{NH})_{2}\left(\mu-\mathrm{NHSiMe}_{3}\right)\right][\mathrm{OTf}]$ with the triflate anion not coordinated to the metals.

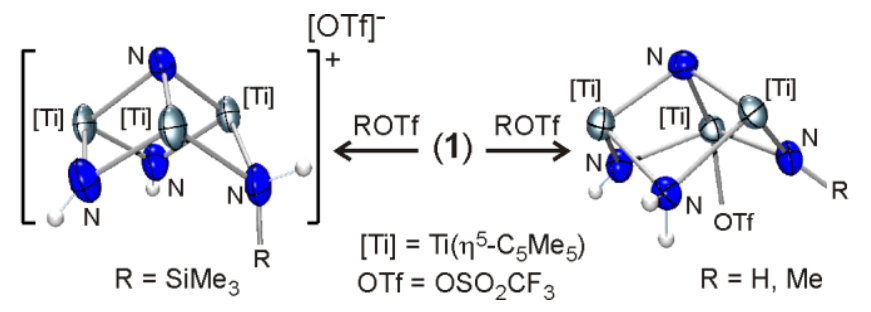




\section{Abstract:}

Several trinuclear titanium complexes bearing amido $\mu$-NHR, imido $\mu-N R$ and nitrido $\mu_{\mathrm{n}}-\mathrm{N}$ ligands have been prepared by reaction of $\left[\left\{\mathrm{Ti}\left(\eta^{5}-\mathrm{C}_{5} \mathrm{Me}_{5}\right)(\mu-\mathrm{NH})\right\}_{3}\left(\mu_{3}-\mathrm{N}\right)\right]$ (1) with one equivalent of electrophilic reagents $\operatorname{ROTf}\left(\mathrm{R}=\mathrm{H}, \mathrm{Me}, \mathrm{SiMe}_{3} ; \mathrm{OTf}=\mathrm{OSO}_{2} \mathrm{CF}_{3}\right)$. Treatment of 1 with triflic acid or methyl triflate in toluene at room temperature affords the precipitation of compounds $\left[\mathrm{Ti}_{3}\left(\eta^{5}-\mathrm{C}_{5} \mathrm{Me}_{5}\right)_{3}\left(\mu_{3}-\mathrm{N}\right)(\mu-\mathrm{NH})_{2}\left(\mu-\mathrm{NH}_{2}\right)(\mathrm{OTf})\right]$ (2) or $\left[\mathrm{Ti}_{3}\left(\eta^{5}-\right.\right.$ $\left.\left.\mathrm{C}_{5} \mathrm{Me}_{5}\right)_{3}\left(\mu_{3}-\mathrm{N}\right)(\mu-\mathrm{NH})\left(\mu-\mathrm{NH}_{2}\right)(\mu-\mathrm{NMe})(\mathrm{OTf})\right](\mathbf{3})$. Complexes 2 and $\mathbf{3}$ exhibit a fluxional behavior in solution consisting of proton exchange between $\mu-\mathrm{NH}_{2}$ and $\mu-\mathrm{NH}$ groups, assisted by the triflato ligand, as could be inferred from a dynamic NMR spectroscopy study. Monitoring by NMR spectroscopy the reaction course of $\mathbf{1}$ with MeOTf allows the characterization of the methylamido intermediate $\left[\mathrm{Ti}_{3}\left(\eta^{5}-\mathrm{C}_{5} \mathrm{Me}_{5}\right)_{3}\left(\mu_{3}-\mathrm{N}\right)(\mu-\mathrm{NH})_{2}(\mu-\right.$ NHMe)(OTf)] (4), which readily rearranges to give 3 by a proton migration from the NHMe amido group to the NH imido ligands. The treatment of $\mathbf{1}$ with one equivalent of $\mathrm{Me}_{3} \mathrm{SiOTf}$ produces the stable ionic complex $\left[\mathrm{Ti}_{3}\left(\eta^{5}-\mathrm{C}_{5} \mathrm{Me}_{5}\right)_{3}\left(\mu_{3}-\mathrm{N}\right)(\mu-\mathrm{NH})_{2}(\mu-\right.$ $\left.\left.\mathrm{NHSiMe}_{3}\right)\right][\mathrm{OTf}](\mathbf{5})$ with a disposition of the nitrogen ligands similar to that of 4 . Complex 5 reacts with one equivalent of $\left[\mathrm{K}\left\{\mathrm{N}\left(\mathrm{SiMe}_{3}\right)_{2}\right\}\right]$ at room temperature to give $\left[\mathrm{Ti}_{3}\left(\eta^{5}-\right.\right.$ $\left.\left.\mathrm{C}_{5} \mathrm{Me}_{5}\right)_{3}\left(\mu_{3}-\mathrm{N}\right)(\mu-\mathrm{N})(\mu-\mathrm{NH})\left(\mu-\mathrm{NHSiMe}_{3}\right)\right] \quad(6)$, which at $85{ }^{\circ} \mathrm{C}$ rearranges to the trimethylsilylimido derivative $\left[\mathrm{Ti}_{3}\left(\eta^{5}-\mathrm{C}_{5} \mathrm{Me}_{5}\right)_{3}\left(\mu_{3}-\mathrm{N}\right)(\mu-\mathrm{NH})_{2}\left(\mu-\mathrm{NSiMe}_{3}\right)\right]$ (7). Treatment of 7 with $\left[\mathrm{K}\left\{\mathrm{N}\left(\mathrm{SiMe}_{3}\right)_{2}\right\}\right]$ affords the potassium derivative $\left[\mathrm{K}\left\{\left(\mu_{3}-\mathrm{N}\right)\left(\mu_{3}-\mathrm{NH}\right)\left(\mu_{3}-\right.\right.\right.$ $\left.\left.\left.\mathrm{NSiMe}_{3}\right) \mathrm{Ti}_{3}\left(\eta^{5}-\mathrm{C}_{5} \mathrm{Me}_{5}\right)_{3}\left(\mu_{3}-\mathrm{N}\right)\right\}\right]$ (8), which upon addition of 18-crown-6 leads to the ion pair $\left[\mathrm{K}\left(18\right.\right.$-crown-6)][Ti $\left.3\left(\eta^{5}-\mathrm{C}_{5} \mathrm{Me}_{5}\right)_{3}\left(\mu_{3}-\mathrm{N}\right)(\mu-\mathrm{N})(\mu-\mathrm{NH})\left(\mu-\mathrm{NSiMe}_{3}\right)\right] \quad(\mathbf{9}) . \quad$ The X-ray crystal structures of $\mathbf{2}, \mathbf{5}, \mathbf{6}$, and $\mathbf{8}$ have been determined. 


\section{Introduction}

An extensive chemistry has been developed with transition metal complexes bearing imido or nitrido ligands as a terminal functionality, $\mathrm{M}=\mathrm{NR}$ or $\mathrm{M} \equiv \mathrm{N} .{ }^{1}$ The reactivity of terminal imido or nitrido ligands has been an area of interest because of their potential to show either electrophilic or nucleophilic character. The behavior of these nitrogen ligands depends on the nature of the metal, its oxidation state, and the ancillary ligands. These factors determine the $\pi$ interaction between the imido or nitrido moiety and the metal center, and considerations based on frontier molecular orbitals have been used to rationalize the increasing electrophilicity of the nitrogen ligand upon going from early to later transition metals. ${ }^{1,2}$ This experimental trend in the reactivity of nitrido complexes has been recently interpreted in terms of the variation of the partial charge on the nitrogen atom. ${ }^{3}$ The reaction of imido or nitrido ligands with nucleophiles leads to a two-electron reduction of the metal center and a reduced bond order between the metal and the nitrogen atom. ${ }^{4,5}$ In contrast, when imido or nitrido ligands react with electrophiles the net result is a reduced bond order between the metal and the nitrogen atom, to produce amido and imido derivatives respectively, with no change in the oxidation state of the metal. ${ }^{6,7}$

While those extensive studies have been mainly carried out on mononuclear midtransition metal (Groups 6-8) complexes bearing terminal imido or nitrido ligands, the reported reactivity of polynuclear early transition metal (Groups 4 and 5) derivatives containing bridging $\left(\mu_{\mathrm{n}}-\mathrm{NR}\right.$ or $\left.\mu_{\mathrm{n}} \mathrm{N}\right)$ ligands remains comparatively scarce..$^{8,9}$ Representative examples include nucleophilic attack of a phosphine to a bridging nitrido ligand in a dinuclear titanium derivative, ${ }^{10}$ or electrophilic attacks on $\mu-\mathrm{N}$ groups of dinuclear titanium, niobium or tantalum complexes generated by dinitrogen activation. ${ }^{11}$ 
During the last decade, we have been involved in the study of the reactivity of the trinuclear imido-nitrido titanium(IV) derivative $\left[\left\{\operatorname{Ti}\left(\eta^{5}-\mathrm{C}_{5} \mathrm{Me}_{5}\right)(\mu-\mathrm{NH})\right\}_{3}\left(\mu_{3}-\mathrm{N}\right)\right]^{12}(\mathbf{1})$. This molecule contains two potentially reactive functionalities: the three $\mu-\mathrm{NH}$ imido groups and the $\mu_{3}-\mathrm{N}$ nitrido ligand. While complex $\mathbf{1}$ is capable of acting as a Lewis base through the imido groups toward many metal derivatives to give cube-type adducts $\left[\mathrm{L}_{n} \mathrm{M}\left\{\left(\mu_{3^{-}}\right.\right.\right.$ $\left.\left.\mathrm{NH})_{3} \mathrm{Ti}_{3}\left(\eta^{5}-\mathrm{C}_{5} \mathrm{Me}_{5}\right)_{3}\left(\mu_{3}-\mathrm{N}\right)\right\}\right],{ }^{13}$ the Lewis base behavior of the apical $\mu_{3}-\mathrm{N}$ nitrido ligand has been only documented with copper and silver MX Lewis acids. ${ }^{14}$ This nitrido ligand is quite chemically unreactive, although we have reported the "apparent" nucleophilic attack of an acetylide group $[\mathrm{C} \equiv \mathrm{CR}]^{-}$at this site to yield alkynylimido $\mu_{3}-\mathrm{NCCR}$ ligands with a two-electron reduction of the $\mathrm{Ti}_{3}$ core. ${ }^{15}$ Density functional theory (DFT) calculations showed that this reaction involves the formation of an alkynyl titanium intermediate followed by migration of the alkynyl group to the apical nitrido ligand. We were interested in studying the reactivity of $\mathbf{1}$ toward electrophiles and here we report on the reaction with one equivalent of ROTf to generate polynuclear complexes by selective functionalization of the imido groups. The preliminary results on the treatment of complex 1 with MeOTf have been recently communicated. ${ }^{16}$ 


\section{Experimental Section}

General Considerations. All manipulations were carried out under argon atmosphere using Schlenk line or glovebox techniques. Toluene and hexane were distilled from $\mathrm{Na} / \mathrm{K}$ alloy just before use. NMR solvents were dried with $\mathrm{Na} / \mathrm{K}$ alloy $\left(\mathrm{C}_{6} \mathrm{D}_{6}, \mathrm{C}_{7} \mathrm{D}_{8}\right)$ or calcium hydride $\left(\mathrm{CDCl}_{3}, \mathrm{C}_{5} \mathrm{D}_{5} \mathrm{~N}\right)$ and vacuum-distilled. Dichloromethane- $\mathrm{d}_{2}$ was dried over activated molecular sieves and stored under argon. Oven-dried glassware was repeatedly evacuated with a pumping system (ca. $1 \times 10^{-3}$ Torr) and subsequently filled with inert gas. $\mathrm{ROSO}_{2} \mathrm{CF}_{3} \quad(\mathrm{R}=\mathrm{H}, \quad \mathrm{Me}, \quad \mathrm{Me} 3 \mathrm{Si}), \quad\left[\mathrm{K}\left\{\mathrm{N}\left(\mathrm{SiMe}_{3}\right)_{2}\right\}\right], \quad$ and $1,4,7,10,13,16-$ hexaoxacyclooctadecane (18-crown-6) were purchased from Aldrich and used as received. $\left[\left\{\mathrm{Ti}\left(\eta^{5}-\mathrm{C}_{5} \mathrm{Me}_{5}\right)(\mu-\mathrm{NH})\right\}_{3}\left(\mu_{3}-\mathrm{N}\right)\right](\mathbf{1})$ was prepared according to a published procedure. ${ }^{12 \mathrm{~b}}$ The syntheses and characterization of complexes $\mathbf{3}$ and $\mathbf{4}$ have been reported previously. ${ }^{16}$

Samples for infrared spectroscopy were prepared as $\mathrm{KBr}$ pellets, and the spectra were obtained using an FT-IR Perkin-Elmer SPECTRUM 2000 spectrophotometer. ${ }^{1} \mathrm{H},{ }^{13} \mathrm{C}\left\{{ }^{1} \mathrm{H}\right\}$ and ${ }^{19} \mathrm{~F}$ NMR spectra were recorded on Varian Unity-300, Mercury-300 and/or Unity-500 Plus spectrometers. Chemical shifts $\left(\delta\right.$, ppm) in the ${ }^{1} \mathrm{H}$ and ${ }^{13} \mathrm{C}\left\{{ }^{1} \mathrm{H}\right\}$ NMR spectra are given relative to residual protons or to carbon of the solvent. Chemical shifts $(\delta, \mathrm{ppm})$ in the ${ }^{19} \mathrm{~F}$ NMR spectra are given relative to $\mathrm{CFCl}_{3}$ as external reference. Microanalyses $(\mathrm{C}, \mathrm{H}, \mathrm{N}, \mathrm{S})$ were performed in a Leco CHNS-932 microanalyzer.

Synthesis of $\left[\mathrm{Ti}_{3}\left(\eta^{5}-\mathrm{C}_{5} \mathrm{Me}_{5}\right)_{3}(\mu 3-\mathrm{N})(\mu-\mathrm{NH})_{2}\left(\mu-\mathrm{NH}_{2}\right)\left(\mathrm{OSO}_{2} \mathrm{CF}_{3}\right)\right]$ (2). A $100 \mathrm{~mL}$ Schlenk flask was charged with $1(0.30 \mathrm{~g}, 0.49 \mathrm{mmol}), \mathrm{HOSO}_{2} \mathrm{CF}_{3}(0.089 \mathrm{~g}, 0.59 \mathrm{mmol})$, and toluene $(10 \mathrm{~mL})$. The reaction mixture was stirred at room temperature for $24 \mathrm{~h}$ to give a yellow solid and an orange solution. The solid was isolated by filtration onto a glass frit and vacuum-dried to afford 2 as a yellow powder $(0.31 \mathrm{~g}, 84 \%)$. IR $\left(\mathrm{KBr}, \mathrm{cm}^{-1}\right): \tilde{v} 3374(\mathrm{w})$, 
3362 (w), 3353 (m), 3250 (m), 2914 (s), 2860 (m), 2727 (w), 1578 (w), 1490 (w), 1436 (m), 1377 (s), 1315 (vs), 1279 (w), 1234 (vs), 1207 (vs), 1199 (vs), 1167 (vs), 1068 (w), 1017 (vs), 779 (vs), 775 (vs), 752 (vs), 708 (m), 678 (s), 634 (s), 548 (m), 508 (m), 485 (w), 461 (w), 420 (w). ${ }^{1} \mathrm{H}$ NMR (300 MHz, $\mathrm{CDCl}_{3}, 20{ }^{\circ} \mathrm{C}$ ): $\delta 12.50$ (s br., $2 \mathrm{H}$; $\mathrm{NH}$ ), 3.28 (s br., $1 \mathrm{H} ; \mathrm{NH} H$ ), 2.01 (s br., $45 \mathrm{H} ; \mathrm{C}_{5} \mathrm{Me}_{5}$ ), one resonance signal for the $\mathrm{NH}_{2}$ ligand was not detected. ${ }^{1} \mathrm{H}$ NMR (500 MHz, $\mathrm{CD}_{2} \mathrm{Cl}_{2}, 20^{\circ} \mathrm{C}$ ): $\delta 13.65$ (s br., 2H; NH), 4.23 (m br., 1H; $\mathrm{NHH}$ ), 3.32 (m br., 1H; NHH), 2.09 (s br., 45H; $\mathrm{C}_{5} \mathrm{Me}_{5}$ ). ${ }^{1} \mathrm{H}$ NMR (500 MHz, $\mathrm{CD}_{2} \mathrm{Cl}_{2},-50$ $\left.{ }^{\circ} \mathrm{C}\right): \delta 13.69$ (s br., $\left.2 \mathrm{H} ; \mathrm{NH}\right), 4.37\left(\mathrm{~d},{ }^{2} J(\mathrm{H}, \mathrm{H})=9.5 \mathrm{~Hz}, 1 \mathrm{H} ; \mathrm{NHH}\right), 3.20\left(\mathrm{~d},{ }^{2} J(\mathrm{H}, \mathrm{H})=9.5\right.$ $\mathrm{Hz}, 1 \mathrm{H} ; \mathrm{NH} H), 2.04\left(\mathrm{~s}, 30 \mathrm{H} ; \mathrm{C}_{5} \mathrm{Me}_{5}\right), 1.92\left(\mathrm{~s}, 15 \mathrm{H} ; \mathrm{C}_{5} \mathrm{Me}_{5}\right) .{ }^{13} \mathrm{C}\left\{{ }^{1} \mathrm{H}\right\} \mathrm{NMR}(75 \mathrm{MHz}$, $\left.\mathrm{CDCl}_{3}, 20^{\circ} \mathrm{C}\right): \delta 121.4$ (s br., $\left.C_{5} \mathrm{Me}_{5}\right), 11.9\left(\mathrm{C}_{5} M e_{5}\right)$, the $\mathrm{CF}_{3}$ carbon atom resonance was not detected. ${ }^{19} \mathrm{~F}$ NMR $\left(282 \mathrm{MHz}, \mathrm{CDCl}_{3}, 20{ }^{\circ} \mathrm{C}\right): \delta$-78.3. Anal. Calcd for $\mathrm{C}_{31} \mathrm{H}_{49} \mathrm{~F}_{3} \mathrm{~N}_{4} \mathrm{O}_{3} \mathrm{STi}_{3}\left(M_{w}=758.41\right): \mathrm{C}$ 49.09, H 6.51, N 7.39, S 4.23. Found: C 49.88, H 6.24, N 7.33, S 4.26 .

Synthesis of $\left[\mathrm{Ti}_{3}\left(\eta^{5}-\mathrm{C}_{5} \mathrm{Me}_{5}\right)_{3}(\mu 3-\mathrm{N})(\mu-\mathrm{NH})_{2}\left(\mu-\mathrm{NHSiMe}_{3}\right)\right]\left[\mathrm{O}_{3} \mathrm{SCF}_{3}\right]$ (5). In a fashion similar to the preparation of 2 , the treatment of $\mathbf{1}(0.60 \mathrm{~g}, 0.98 \mathrm{mmol})$ with $\mathrm{Me}_{3} \mathrm{SiOSO}_{2} \mathrm{CF}_{3}$ $(0.22 \mathrm{~g}, 0.99 \mathrm{mmol})$ in toluene $(10 \mathrm{~mL})$ for $24 \mathrm{~h}$ afforded 5 as an orange powder $(0.72 \mathrm{~g}$, 88\%). IR (KBr, $\left.\mathrm{cm}^{-1}\right): \tilde{v} 3271$ (m, broad), 2952 (m), 2914 (s), 1489 (w), 1428 (m), $1380(\mathrm{~s})$, 1252 (vs), 1222 (s), 1200 (m), 1149 (vs), 1031 (vs), 951 (w), 840 (vs), 761 (vs), 736 (vs), 711 (vs), 666 (vs), 637 (vs), 571 (m), 517 (m), 461 (m), 422 (w). ${ }^{1} \mathrm{H}$ NMR (300 MHz, $\mathrm{CDCl}_{3}, 20^{\circ} \mathrm{C}$ ): $\delta 14.10$ (s br., 2H; NH), 4.92 (s, 1H; $\left.\mathrm{NHSiMe}_{3}\right), 2.12$ (s, 30H; $\left.\mathrm{C}_{5} \mathrm{Me}_{5}\right), 2.01$

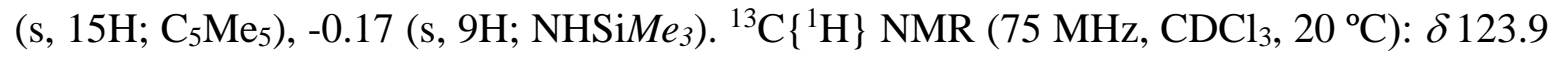
$\left(C_{5} \mathrm{Me}_{5}\right), 123.3\left(C_{5} \mathrm{Me}_{5}\right), 12.7\left(\mathrm{C}_{5} \mathrm{Me}_{5}\right), 11.9\left(\mathrm{C}_{5} M e_{5}\right), 4.8\left(\mathrm{SiMe}_{3}\right)$, the $\mathrm{CF}_{3}$ carbon atom resonance was not detected. ${ }^{19} \mathrm{~F} \mathrm{NMR}\left(282 \mathrm{MHz}, \mathrm{CDCl}_{3}, 20{ }^{\circ} \mathrm{C}\right): \delta$-77.9. Anal. Calcd for 
$\mathrm{C}_{34} \mathrm{H}_{57} \mathrm{~F}_{3} \mathrm{~N}_{4} \mathrm{O}_{3} \mathrm{SSiTi}_{3}\left(M_{w}=830.59\right): \mathrm{C} 49.17, \mathrm{H}$ 6.92, N 6.75, S 3.86. Found: C 48.83, H 6.44, N 6.72, S 3.48.

Synthesis of $\left[\mathbf{T i}_{3}\left(\eta^{5}-\mathrm{C}_{5} \mathrm{Me}_{5}\right)_{3}\left(\mu_{3}-\mathrm{N}\right)(\mu-\mathrm{N})(\mu-\mathrm{NH})(\mu-\mathrm{NHSiMe})\right](6)$. A $100 \mathrm{~mL}$ Schlenk flask was charged with $5(0.30 \mathrm{~g}, 0.36 \mathrm{mmol}),\left[\mathrm{K}\left\{\mathrm{N}\left(\mathrm{SiMe}_{3}\right)_{2}\right\}\right](0.080 \mathrm{~g}, 0.40 \mathrm{mmol})$, and toluene $(20 \mathrm{~mL})$. The reaction mixture was stirred at room temperature for $30 \mathrm{~min}$ to give a red solution and a white fine solid. After filtration, the volatile components of the solution were removed under reduced pressure and the resultant dark red solid was vacuum-dried for $3 \mathrm{~h}$ to give $6(0.17 \mathrm{~g}, 69 \%)$. IR $\left(\mathrm{KBr}, \mathrm{cm}^{-1}\right): \tilde{v} 3353(\mathrm{w}), 3273(\mathrm{w}), 2909(\mathrm{~s}), 2857(\mathrm{~s})$, 2721 (w), 1495 (w), 1435 (m), 1374 (m), 1261 (w), 1246 (m), 1167 (w), 1066 (w), 1030 (m), 956 (w), 838 (s), 783 (s), $764(\mathrm{~s}), 731$ (s), 703 (s), 609 (s), $516(\mathrm{~m}), 482(\mathrm{w}), 466(\mathrm{w})$, 422 (m). ${ }^{1} \mathrm{H}$ NMR (300 MHz, $\mathrm{C}_{6} \mathrm{D}_{6}, 20{ }^{\circ} \mathrm{C}$ ): $\delta 12.84$ (s br., 1H; NH), 3.72 (s br., $1 \mathrm{H}$; NHSiMe 3 ), 2.14 (s, 15H; C5 $\mathrm{Me}_{5}$ ), 2.03 (s, 15H; $\mathrm{C}_{5} \mathrm{Me}_{5}$ ), 1.94 (s, 15H; $\mathrm{C}_{5} \mathrm{Me}_{5}$ ), 0.25 (s, 9H; NHSiMe $).{ }^{13} \mathrm{C}\left\{{ }^{1} \mathrm{H}\right\}$ NMR $\left(75 \mathrm{MHz}, \mathrm{C}_{6} \mathrm{D}_{6}, 20{ }^{\circ} \mathrm{C}\right): \delta 118.3\left(C_{5} \mathrm{Me}_{5}\right), 117.4\left(C_{5} \mathrm{Me}_{5}\right), 117.1$ $\left(C_{5} \mathrm{Me}_{5}\right), 12.5\left(\mathrm{C}_{5} M e_{5}\right), 12.4\left(\mathrm{C}_{5} \mathrm{Me}_{5}\right), 12.0\left(\mathrm{C}_{5} M e_{5}\right), 5.7\left(\mathrm{SiMe}_{3}\right)$. Anal. Calcd for $\mathrm{C}_{33} \mathrm{H}_{56} \mathrm{~N}_{4} \mathrm{SiTi}_{3}\left(M_{w}=680.51\right)$ : C 58.24, H 8.29, N 8.23. Found: C 57.97, H 8.08, N 7.59.

Synthesis of $\left[\mathrm{Ti}_{3}\left(\eta^{5}-\mathrm{C}_{5} \mathrm{Me}_{5}\right)_{3}\left(\mu_{3}-\mathrm{N}\right)(\boldsymbol{\mu}-\mathbf{N H})_{2}(\mu-\mathrm{NSiMe})\right]$ (7). A $100 \mathrm{~mL}$ ampule (Teflon stopcock) was charged with $5(0.30 \mathrm{~g}, 0.36 \mathrm{mmol}),\left[\mathrm{K}\left\{\mathrm{N}\left(\mathrm{SiMe}_{3}\right)_{2}\right\}\right](0.080 \mathrm{~g}, 0.40 \mathrm{mmol})$ and toluene $(20 \mathrm{~mL})$. The reaction mixture was stirred at $85^{\circ} \mathrm{C}$ for $16 \mathrm{~h}$. After filtration, the volatile components of the solution were removed under reduced pressure to give $\mathbf{7}$ as an orange solid $(0.17 \mathrm{~g}, 69 \%) .{ }^{1} \mathrm{H}$ NMR $\left(300 \mathrm{MHz}, \mathrm{C}_{6} \mathrm{D}_{6}, 20{ }^{\circ} \mathrm{C}\right): \delta 14.22$ (s br., $\left.2 \mathrm{H} ; \mathrm{NH}\right)$, 2.09 (s, 30H; $\left.\mathrm{C}_{5} \mathrm{Me}_{5}\right), 1.88$ (s, 15H; $\left.\mathrm{C}_{5} \mathrm{Me}_{5}\right), 0.15$ (s, 9H; $\left.\mathrm{NSiMe}_{3}\right) .{ }^{13} \mathrm{C}\left\{{ }^{1} \mathrm{H}\right\} \mathrm{NMR}(75$ $\left.\mathrm{MHz}, \mathrm{C}_{6} \mathrm{D}_{6}, 20{ }^{\circ} \mathrm{C}\right): \delta 118.2\left(C_{5} \mathrm{Me}_{5}\right), 117.8\left(C_{5} \mathrm{Me}_{5}\right), 12.5\left(\mathrm{C}_{5} M e_{5}\right), 11.8\left(\mathrm{C}_{5} M e_{5}\right), 7.0$ 
$\left(\mathrm{SiMe}_{3}\right)$. Compound 7 has been previously prepared in $59 \%$ yield by a different procedure. $^{17}$

Synthesis of $\left[\mathrm{K}\left\{\left(\mu_{3}-\mathrm{N}\right)\left(\mu_{3}-\mathrm{NH}\right)\left(\mu_{3}-\mathrm{NSiMe}\right) \mathrm{Ti}_{3}\left(\eta^{5}-\mathrm{C}_{5} \mathrm{Me}_{5}\right)_{3}\left(\mu_{3}-\mathrm{N}\right)\right\}\right] \quad(8)$. A $100 \mathrm{~mL}$ ampule (Teflon stopcock) was charged with $5(0.30 \mathrm{~g}, 0.36 \mathrm{mmol}),\left[\mathrm{K}\left\{\mathrm{N}\left(\mathrm{SiMe}_{3}\right)_{2}\right\}\right](0.16$ $\mathrm{g}, 0.80 \mathrm{mmol})$, and toluene $(30 \mathrm{~mL})$. The reaction mixture was stirred at $85{ }^{\circ} \mathrm{C}$ for $24 \mathrm{~h}$. After filtration, the volatile components of the solution were removed under reduced pressure to give 8 as a red solid $(0.23 \mathrm{~g}, 89 \%)$. IR $\left(\mathrm{KBr}, \mathrm{cm}^{-1}\right): \tilde{v} 3325(\mathrm{w}), 2905(\mathrm{~s}), 2856$ (s), $2720(\mathrm{w}), 1496(\mathrm{w}), 1437(\mathrm{~m}), 1374(\mathrm{~m}), 1257(\mathrm{~m}), 1244(\mathrm{~s}), 1095(\mathrm{w}), 1065(\mathrm{w}), 1023$ (m), 956 (vs), 822 (s), 731 (vs), 702 (s), 662 (s), 629 (s), 593 (w), 548 (w), 510 (w), 473 (m), 415 (w). ${ }^{1} \mathrm{H}$ NMR (300 MHz, $\mathrm{C}_{6} \mathrm{D}_{6}, 20^{\circ} \mathrm{C}$ ): $\delta 13.34$ (s br., 1H; NH), 2.30 (s, 15H; $\mathrm{C}_{5} \mathrm{Me}_{5}$ ), 2.13 (s, 15H; $\mathrm{C}_{5} \mathrm{Me}_{5}$ ), 2.11 (s, 15H; $\mathrm{C}_{5} \mathrm{Me}_{5}$ ), 0.11 (s, 9H; NSiMe 3 ). ${ }^{1} \mathrm{H}$ NMR (300 $\mathrm{MHz}, \mathrm{C}_{5} \mathrm{D}_{5} \mathrm{~N}, 20^{\circ} \mathrm{C}$ ): $\delta 13.92$ (s br., $\left.1 \mathrm{H} ; \mathrm{NH}\right), 2.28$ (s, 15H; $\left.\mathrm{C}_{5} \mathrm{Me}_{5}\right), 2.15$ (s, 15H; $\mathrm{C}_{5} \mathrm{Me}_{5}$ ), 2.05 (s, 15H; $\left.\mathrm{C}_{5} \mathrm{Me}_{5}\right), 0.30$ (s, 9H; NSiMe $) .{ }^{13} \mathrm{C}\left\{{ }^{1} \mathrm{H}\right\} \mathrm{NMR}\left(75 \mathrm{MHz}, \mathrm{C}_{6} \mathrm{D}_{6}, 20{ }^{\circ} \mathrm{C}\right): \delta$ $116.6\left(C_{5} \mathrm{Me}_{5}\right), 115.9\left(C_{5} \mathrm{Me}_{5}\right), 113.9\left(C_{5} \mathrm{Me}_{5}\right), 13.0\left(\mathrm{C}_{5} \mathrm{Me}_{5}\right), 12.8\left(\mathrm{C}_{5} M e_{5}\right), 12.5\left(\mathrm{C}_{5} M e_{5}\right)$, $9.0\left(\mathrm{SiMe}_{3}\right) .{ }^{13} \mathrm{C}\left\{{ }^{1} \mathrm{H}\right\}$ NMR $\left(75 \mathrm{MHz}, \mathrm{C}_{5} \mathrm{D}_{5} \mathrm{~N}, 20{ }^{\circ} \mathrm{C}\right): \delta 115.4\left(C_{5} \mathrm{Me}_{5}\right), 114.4\left(C_{5} \mathrm{Me}_{5}\right)$, $113.3\left(C_{5} \mathrm{Me}_{5}\right), 12.7\left(\mathrm{C}_{5} M e_{5}\right), 12.5\left(\mathrm{C}_{5} \mathrm{Me}_{5}\right), 12.0\left(\mathrm{C}_{5} \mathrm{Me}_{5}\right), 8.4\left(\mathrm{SiMe}_{3}\right)$. Anal. Calcd for $\mathrm{C}_{33} \mathrm{H}_{55} \mathrm{KN}_{4} \mathrm{SiTi}_{3}\left(M_{w}=718.60\right)$ : C 55.16, H 7.71, N 7.80. Found: C 54.89, H 7.90, N 7.76.

\section{Synthesis of $[K(18-c r o w n-6)]\left[T_{3}\left(\eta^{5}-C_{5} M_{5}\right) 3(\mu 3-N)(\mu-N)(\mu-N H)(\mu-N S i M e 3)\right] \quad(9)$ A}

toluene solution $(10 \mathrm{~mL})$ of 18 -crown-6 $(0.074 \mathrm{~g}, 0.28 \mathrm{mmol})$ was added to a solution of $\mathbf{8}$ $(0.20 \mathrm{~g}, 0.28 \mathrm{mmol})$ in toluene $(15 \mathrm{~mL})$. The reaction mixture was stirred at room temperature for 5 min to give an abundant yellow solid. The solid was isolated by filtration onto a glass frit and vacuum-dried to afford 9 as a yellow powder $(0.22 \mathrm{~g}, 80 \%)$. IR (KBr, $\left.\mathrm{cm}^{-1}\right): \tilde{v} 3348(\mathrm{w}), 2901(\mathrm{vs}), 2747(\mathrm{~m}), 2715(\mathrm{~m}), 1496(\mathrm{w}), 1472(\mathrm{~m}), 1452(\mathrm{~m}), 1372(\mathrm{~m})$ 
1352 (s), 1286 (w), 1249 (s), 1230 (s), 1105 (vs), 960 (s), 939 (s), 826 (s), 744 (vs), 686 (s), 623 (s), 514 (m), 487 (m), 441 (w). ${ }^{1} \mathrm{H}$ NMR (300 MHz, $\left.\mathrm{C}_{5} \mathrm{D}_{5} \mathrm{~N}, 20{ }^{\circ} \mathrm{C}\right): \delta 14.09$ (s br., $1 \mathrm{H}$; $\mathrm{NH}), 3.41\left(\mathrm{~s}, 24 \mathrm{H} ; \mathrm{OCH}_{2}\right), 2.44\left(\mathrm{~s}, 15 \mathrm{H} ; \mathrm{C}_{5} \mathrm{Me}_{5}\right), 2.31\left(\mathrm{~s}, 15 \mathrm{H} ; \mathrm{C}_{5} \mathrm{Me}_{5}\right), 2.26(\mathrm{~s}, 15 \mathrm{H}$; $\left.\mathrm{C}_{5} \mathrm{Me}_{5}\right), 0.48$ (s, 9H; $\left.\mathrm{NSiMe}_{3}\right) .{ }^{13} \mathrm{C}\left\{{ }^{1} \mathrm{H}\right\}$ NMR $\left(75 \mathrm{MHz}, \mathrm{C}_{5} \mathrm{D}_{5} \mathrm{~N}, 20{ }^{\circ} \mathrm{C}\right): \delta 113.9\left(C_{5} \mathrm{Me}_{5}\right)$, $113.0\left(C_{5} \mathrm{Me}_{5}\right), 112.6\left(C_{5} \mathrm{Me}_{5}\right), 70.0\left(\mathrm{OCH}_{2}\right), 12.8\left(\mathrm{C}_{5} M e_{5}\right), 12.6\left(\mathrm{C}_{5} \mathrm{Me}_{5}\right), 12.3\left(\mathrm{C}_{5} \mathrm{Me}_{5}\right)$, 8.3 ( $\left.\mathrm{SiMe}_{3}\right)$. Anal. Calcd for $\mathrm{C}_{45} \mathrm{H}_{79} \mathrm{KN}_{4} \mathrm{O}_{6} \mathrm{SiTi}_{3}\left(M_{w}=982.91\right)$ : C 54.99, H 8.10, N 5.70. Found: C 55.17, H 7.91, N 5.30.

X-ray structure determination of 2, 5, 6 and 8. Crystals of complexes 2 and 6 were grown from toluene solutions at $-35^{\circ} \mathrm{C}$. Crystals of complexes $\mathbf{5}$ and $\mathbf{8}$ were obtained from toluene solutions at room temperature. The crystals were removed from the Schlenk flasks and covered with a layer of a viscous perfluoropolyether (Fomblin $\left.{ }^{\circledR} Y\right)$. A suitable crystal was selected with the aid of a microscope, mounted on a cryoloop, and immediately placed in the low temperature nitrogen stream of the diffractometer. The intensity data sets were collected at $200 \mathrm{~K}$ on a Bruker-Nonius KappaCCD diffractometer equipped with an Oxford Cryostream 700 unit. Crystallographic data for all the complexes are presented in Table 1. 
Table 1. Experimental Data for the X-ray Diffraction Studies on Compounds 2, 5, 6, and 8.

\begin{tabular}{|c|c|c|c|c|}
\hline & 2 & 5 & 6 & 8 \\
\hline Formula & $\mathrm{C}_{31} \mathrm{H}_{49} \mathrm{~F}_{3} \mathrm{~N}_{4} \mathrm{O}_{3} \mathrm{STi}_{3}$ & $\mathrm{C}_{34} \mathrm{H}_{57} \mathrm{~F}_{3} \mathrm{~N}_{4} \mathrm{O}_{3} \mathrm{SSiTi}_{3}$ & $\mathrm{C}_{33} \mathrm{H}_{56} \mathrm{~N}_{4} \mathrm{SiTi}_{3}$ & $\mathrm{C}_{33} \mathrm{H}_{55} \mathrm{KN}_{4} \mathrm{SiTi}_{3}$ \\
\hline$M_{\mathrm{r}}$ & 758.50 & 830.69 & 680.61 & 718.70 \\
\hline$T[\mathrm{~K}]$ & $200(2)$ & $200(2)$ & $200(2)$ & $200(2)$ \\
\hline$\lambda[\AA]$ & 0.71073 & 0.71073 & 0.71073 & 0.71073 \\
\hline crystal system & Monoclinic & Orthorhombic & Triclinic & Monoclinic \\
\hline space group & $P 2_{1} / c$ & Pbca & $P-1$ & $P 2_{1} / c$ \\
\hline$a[\AA] ; \alpha\left[^{\circ}\right]$ & $11.864(2)$ & $19.579(14)$ & $11.293(6) ; 95.11(3)$ & 10.918(9) \\
\hline$b[\AA] ; \beta\left[^{\circ}\right]$ & $\begin{array}{l}\text { 19.143(4); } \\
117.84(1)\end{array}$ & $20.000(6)$ & $\begin{array}{l}\text { 12.691(1); } \\
100.16(3)\end{array}$ & $\begin{array}{l}16.303(8) \\
115.38(4)\end{array}$ \\
\hline$c[\AA] ; \gamma\left[{ }^{\circ}\right]$ & $18.043(3)$ & $21.224(1)$ & $12.788(7) ; 98.30(3)$ & $22.856(11)$ \\
\hline$V\left[\AA^{3}\right]$ & $3264(1)$ & $8311(6)$ & $1773(1)$ & $3676(4)$ \\
\hline $\mathrm{Z}$ & 4 & 8 & 2 & 4 \\
\hline$\rho_{\text {calcd }}\left[\mathrm{g} \mathrm{cm}^{-3}\right]$ & 1.390 & 1.328 & 1.275 & 1.299 \\
\hline$\mu_{\mathrm{MoK} \alpha}\left[\mathrm{mm}^{-1}\right]$ & 0.754 & 0.691 & 0.720 & 0.809 \\
\hline$F(000)$ & 1584 & 3488 & 724 & 1520 \\
\hline crystal size $\left[\mathrm{mm}^{3}\right]$ & $0.22 \times 0.20 \times 0.17$ & $0.16 \times 0.15 \times 0.14$ & $0.27 \times 0.23 \times 0.20$ & $0.25 \times 0.13 \times 0.12$ \\
\hline$\theta$ range (deg) & 3.19 to 27.51 & 3.01 to 26.17 & 3.26 to 27.50 & 3.06 to 27.51 \\
\hline index ranges & -15 to 15 & -24 to 24 & -14 to 14 & -14 to 14 \\
\hline & -24 to 24 & -24 to 24 & -15 to 16 & -21 to 21 \\
\hline & -15 to 23 & -26 to 26 & -16 to 16 & -29 to 14 \\
\hline Reflections collected & 86270 & 225003 & 71530 & 73443 \\
\hline Unique data & $\begin{array}{l}8304[\mathrm{R}(\text { int })= \\
0.051]\end{array}$ & $\begin{array}{l}8226[\mathrm{R}(\text { int })= \\
0.197]\end{array}$ & $\begin{array}{l}8151[\mathrm{R}(\text { int })= \\
0.073]\end{array}$ & $\begin{array}{l}8449[\mathrm{R}(\mathrm{int})= \\
0.097]\end{array}$ \\
\hline obsd data $[\mathrm{I}>2 \sigma(\mathrm{I})]$ & 5593 & 5083 & 5849 & 4692 \\
\hline Goodness-of-fit on $\mathrm{F}^{2}$ & 1.035 & 1.038 & 1.055 & 1.015 \\
\hline $\begin{array}{l}\text { final } \mathrm{R}^{a} \text { indices } \\
{[\mathrm{I}>2 \sigma(\mathrm{I})]}\end{array}$ & $\begin{array}{l}\mathrm{R} 1=0.049, \\
\mathrm{wR} 2=0.110\end{array}$ & $\begin{array}{l}\mathrm{R} 1=0.073 \\
\mathrm{wR} 2=0.172\end{array}$ & $\begin{array}{l}\mathrm{R} 1=0.052 \\
\mathrm{wR} 2=0.136\end{array}$ & $\begin{array}{l}\mathrm{R} 1=0.068 \\
\mathrm{wR} 2=0.133\end{array}$ \\
\hline$R^{a}$ indices (all data) & $\begin{array}{l}\mathrm{R} 1=0.090 \\
\mathrm{wR} 2=0.124\end{array}$ & $\begin{array}{l}\mathrm{R} 1=0.131 \\
\mathrm{wR} 2=0.219\end{array}$ & $\begin{array}{l}\mathrm{R} 1=0.083 \\
\mathrm{wR} 2=0.150\end{array}$ & $\begin{array}{l}\mathrm{R} 1=0.144, \\
\mathrm{wR} 2=0.155\end{array}$ \\
\hline $\begin{array}{l}\text { largest diff. } \\
\text { peak/hole }\left[\mathrm{e} . \AA^{-3}\right]\end{array}$ & 0.349 and -0.623 & 0.787 and -0.597 & 0.504 and -0.565 & 0.991 and -0.496 \\
\hline
\end{tabular}

${ }^{a} R l=\Sigma|| F_{0}|-| F_{c} \| /\left[\Sigma\left|F_{0}\right|\right] \quad w R 2=\left\{\left[\Sigma w\left(F_{0}^{2}-F_{c}^{2}\right)^{2}\right] /\left[\Sigma w\left(F_{0}^{2}\right)^{2}\right]\right\}^{1 / 2}$

The structures were solved, using the WINGX package, ${ }^{18}$ by direct methods (SHELXS-97) and refined by least-squares against $\mathrm{F}^{2}$ (SHELXL-97). ${ }^{19}$ In the crystallographic study of compound 2, all non-hydrogen atoms were anisotropically refined. All the hydrogen atoms were positioned geometrically and refined by using a riding model, except those of the imido $(\mathrm{H}(12)$ and $\mathrm{H}(23))$ and amido $(\mathrm{H}(13 \mathrm{a})$ and $\mathrm{H}(13 \mathrm{~b}))$ 
groups, which were located in the difference Fourier map and refined isotropically. Moreover, SADI restraints were employed for the lengths N(12)-H(12) and N(23)-H(23).

Anion $\mathrm{CF}_{3} \mathrm{SO}_{3}{ }^{-}$in complex 5 presented disorder, which was treated conventionally by using the PART tool of the SHELXL-97 program and allowing free refinement of the occupancy factors with the FVAR command. The final values of occupancy were 55 and 45\%. All non-hydrogen atoms were anisotropically refined, except fluorine and oxygen atoms for the triflate group $(\mathrm{F}(1), \mathrm{F}(2), \mathrm{F}(3), \mathrm{F}(1)$ ', $\mathrm{F}(2)$ ', $\mathrm{F}(3)$ ', $\mathrm{O}(1), \mathrm{O}(2), \mathrm{O}(3), \mathrm{O}(1)$ ', $\mathrm{O}(2)^{\prime}$ and $\left.\mathrm{O}(3)^{\prime}\right)$, which were refined isotropically. The hydrogen atoms were positioned geometrically and refined using a riding model. Furthermore, DFIX restraints were used for the triflate anion.

Crystals of the complex 6 showed disorder for the carbon atoms $\mathrm{C}(11)-\mathrm{C}(20)$ of the pentamethylcyclopentadienyl ligand linked to $\mathrm{Ti}(1)$. This disorder was also treated using the PART tool, and the final values of occupancy were 62.0 and $38.0 \%$. All non-hydrogen atoms were anisotropically refined. The amido group hydrogen atom, H(12), was located in the difference Fourier map and refined isotropically, whereas the rest of the hydrogen atoms were positioned geometrically and refined using a riding model. The imido hydrogen atom was distributed over the nitrogen atoms $\mathrm{N}(13)$ and $\mathrm{N}(23)$ with $50 \%$ of occupancy for each position. The non-disordered pentamethylcyclopentadienyl groups, linked to Ti(2) and Ti(3), were restrained with DELU instructions.

Finally, the solid-state structure of compound $\mathbf{8}$ revealed a one-dimensional polymeric network. All the non-hydrogen atoms were anisotropically refined, whereas all the hydrogen atoms were positioned geometrically and refined by using a riding model, except that of the imido group $(\mathrm{H}(23))$, which was located in the difference Fourier map and refined isotropically. 


\section{Results and Discussion}

The treatment of $\left[\left\{\mathrm{Ti}\left(\eta^{5}-\mathrm{C}_{5} \mathrm{Me}_{5}\right)(\mu-\mathrm{NH})\right\}_{3}\left(\mu_{3}-\mathrm{N}\right)\right](\mathbf{1})$ with one equivalent of triflic acid or methyl triflate in toluene at room temperature afforded the precipitation of complexes $\left[\mathrm{Ti}_{3}\left(\eta^{5}-\mathrm{C}_{5} \mathrm{Me}_{5}\right)_{3}\left(\mu_{3}-\mathrm{N}\right)(\mu-\mathrm{NH})_{2}\left(\mu-\mathrm{NH}_{2}\right)\left(\mathrm{OSO}_{2} \mathrm{CF}_{3}\right)\right](2)$ or $\left[\mathrm{Ti}_{3}\left(\eta^{5}-\mathrm{C}_{5} \mathrm{Me}_{5}\right)_{3}\left(\mu_{3-}\right.\right.$ $\left.\mathrm{N})(\mu-\mathrm{NH})\left(\mu-\mathrm{NH}_{2}\right)(\mu-\mathrm{NMe})\left(\mathrm{OSO}_{2} \mathrm{CF}_{3}\right)\right]$ (3) (Scheme 1). Compounds 2 and 3 were isolated in good yields (84 and 78\%, respectively) as yellow or orange solids which are very soluble in halogenated solvents, moderately soluble in toluene or benzene, and insoluble in hexane.

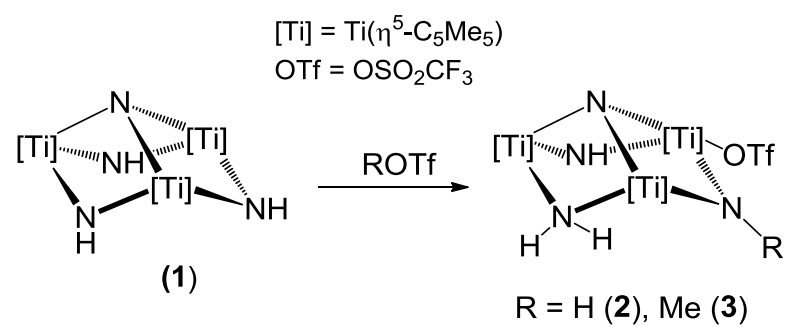

Scheme 1. Reaction of 1 with one equivalent of ROTf $(\mathrm{R}=\mathrm{H}, \mathrm{Me})$.

Complexes $\mathbf{2}$ and $\mathbf{3}$ were characterized by analytical and spectroscopic methods, as well as by X-ray crystal structure determinations. The solid-state structure of $\mathbf{2}$ is shown in Figure 1, which is almost identical to that reported for complex $\mathbf{3}$ with the substitution of the methylimido group for a $\mu-\mathrm{NH}$ ligand. ${ }^{16}$ Selected distances and angles for both structures are compared in Table 2, showing very similar values for the two compounds. The crystal structures show six-membered $\mathrm{Ti}_{3} \mathrm{~N}_{3}$ rings in chair conformation with the three titanium atoms also bridged by a further nitrogen atom. Two of the titanium atoms, Ti(1) and $\operatorname{Ti}(3)$, have classical three-legged piano-stool arrangements, where the legs are occupied by one $\mu-\mathrm{NH}_{2}$ amido, one $\mu_{3}-\mathrm{N}$ nitrido and a $\mu-\mathrm{NR}$ imido ligand. The Ti(2) atoms 
exhibit four-legged piano-stool arrangements, in which the legs are occupied by one triflato, one nitrido, and two imido ligands.

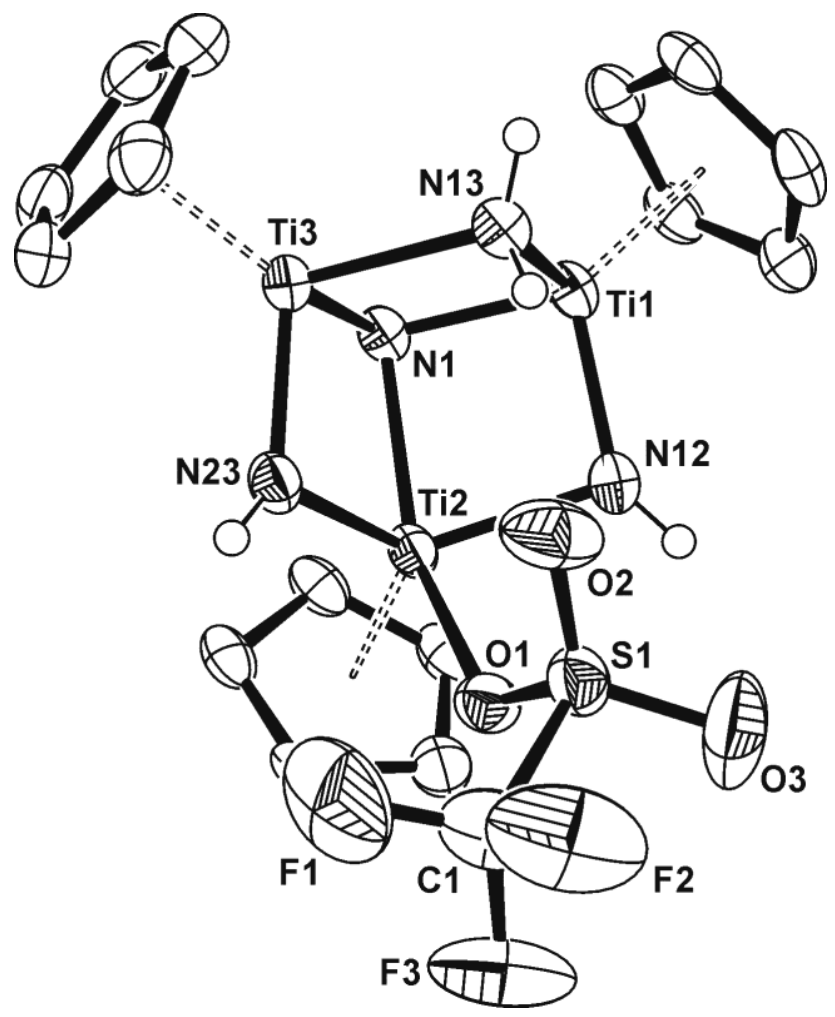

Figure 1. Perspective view of complex 2 (thermal ellipsoids at the $50 \%$ probability level).

The methyl groups of the pentamethylcyclopentadienyl ligands are omitted for clarity.

Table 2. Selected Lengths ( $)$ and Angles (deg) for Complexes 2 and 3.

\begin{tabular}{lcclrr}
\hline Lengths & $\mathbf{2}$ & $\mathbf{3}$ & Angles & $\mathbf{2}$ & $\mathbf{3}$ \\
\hline $\operatorname{Ti}(1)-\mathrm{N}(1)$ & $1.866(2)$ & $1.868(3)$ & $\mathrm{N}(1)-\mathrm{Ti}(1)-\mathrm{N}(12)$ & $90.3(1)$ & $88.7(1)$ \\
$\operatorname{Ti}(1)-\mathrm{N}(12)$ & $1.858(3)$ & $1.831(3)$ & $\mathrm{N}(1)-\mathrm{Ti}(1)-\mathrm{N}(13)$ & $85.3(1)$ & $85.1(1)$ \\
$\operatorname{Ti}(1)-\mathrm{N}(13)$ & $2.107(3)$ & $2.102(3)$ & $\mathrm{N}(12)-\mathrm{Ti}(1)-\mathrm{N}(13)$ & $101.0(1)$ & $102.2(1)$ \\
$\operatorname{Ti}(2)-\mathrm{N}(1)$ & $2.137(2)$ & $2.084(3)$ & $\mathrm{N}(1)-\mathrm{Ti}(2)-\mathrm{N}(12)$ & $79.6(1)$ & $78.9(1)$ \\
$\operatorname{Ti}(2)-\mathrm{N}(12)$ & $1.986(2)$ & $1.983(3)$ & $\mathrm{N}(1)-\mathrm{Ti}(2)-\mathrm{N}(23)$ & $78.4(1)$ & $80.5(1)$ \\
$\operatorname{Ti}(2)-\mathrm{N}(23)$ & $1.975(2)$ & $2.000(3)$ & $\mathrm{N}(12)-\mathrm{Ti}(2)-\mathrm{N}(23)$ & $118.9(1)$ & $118.8(1)$
\end{tabular}




\begin{tabular}{lrllrr}
$\mathrm{Ti}(2)-\mathrm{O}(1)$ & $2.172(2)$ & $2.157(3)$ & $\mathrm{N}(1)-\mathrm{Ti}(2)-\mathrm{O}(1)$ & $145.0(1)$ & $145.0(1)$ \\
$\mathrm{Ti}(3)-\mathrm{N}(1)$ & $1.877(2)$ & $1.868(3)$ & $\mathrm{N}(12)-\mathrm{Ti}(2)-\mathrm{O}(1)$ & $84.2(1)$ & $82.1(1)$ \\
$\mathrm{Ti}(3)-\mathrm{N}(13)$ & $2.103(2)$ & $2.099(3)$ & $\mathrm{N}(23)-\mathrm{Ti}(2)-\mathrm{O}(1)$ & $82.9(1)$ & $83.3(1)$ \\
$\mathrm{Ti}(3)-\mathrm{N}(23)$ & $1.844(3)$ & $1.856(3)$ & $\mathrm{N}(1)-\mathrm{Ti}(3)-\mathrm{N}(13)$ & $85.1(1)$ & $85.2(1)$ \\
$\operatorname{Ti}(1) \cdots \operatorname{Ti}(2)$ & $2.874(1)$ & $2.866(1)$ & $\mathrm{N}(1)-\mathrm{Ti}(3)-\mathrm{N}(23)$ & $88.7(1)$ & $90.3(1)$ \\
$\mathrm{Ti}(1) \cdots \operatorname{Ti}(3)$ & $2.910(1)$ & $2.905(1)$ & $\mathrm{N}(13)-\mathrm{Ti}(3)-\mathrm{N}(23)$ & $101.5(1)$ & $101.2(1)$ \\
$\mathrm{Ti}(2) \cdots \operatorname{Ti}(3)$ & $2.895(1)$ & $2.853(1)$ & $\mathrm{Ti}(1)-\mathrm{N}(1)-\mathrm{Ti}(2)$ & $91.5(1)$ & $92.8(1)$ \\
$\mathrm{N}(23)-\mathrm{C}(1)$ & & $1.467(5)$ & $\mathrm{Ti}(1)-\mathrm{N}(1)-\mathrm{Ti}(3)$ & $102.1(1)$ & $102.1(1)$ \\
& & & $\mathrm{Ti}(2)-\mathrm{N}(1)-\mathrm{Ti}(3)$ & $92.1(1)$ & $92.3(1)$ \\
& & & $\mathrm{Ti}(1)-\mathrm{N}(12)-\mathrm{Ti}(2)$ & $96.8(1)$ & $97.4(1)$ \\
& & & $\mathrm{Ti}(1)-\mathrm{N}(13)-\mathrm{Ti}(3)$ & $87.5(1)$ & $87.5(1)$ \\
& & & $\mathrm{Ti}(2)-\mathrm{N}(23)-\mathrm{Ti}(3)$ & $98.5(1)$ & $95.4(1)$ \\
& & & $\mathrm{Ti}(2)-\mathrm{N}(23)-\mathrm{C}(1)$ & & $124.4(3)$ \\
& & $\mathrm{Ti}(3)-\mathrm{N}(23)-\mathrm{C}(1)$ & & $140.2(3)$ \\
\hline
\end{tabular}

The $\mathrm{NH}_{2}$ amido group bridges the titanium(1) and titanium(3) atoms in a symmetric fashion with $\mathrm{Ti}-\mathrm{N}(13)$ bond lengths, 2.099(3)-2.107(3) $\AA$, that are about $0.25 \AA$ longer than the distances between those titanium atoms and the imido ligands, $\operatorname{Ti}(1)-\mathrm{N}(12)$ and $\mathrm{Ti}(3)-\mathrm{N}(23)$ of $1.831(3)-1.858(3) \AA$. The nitrido group $\mathrm{N}(1)$ also bridges symmetrically the $\operatorname{Ti}(1)$ and $\operatorname{Ti}(3)$ atoms with values of titanium-nitrogen bond lengths $(1.866(2)-1.877(2) \AA)$ in the upper limit of those found in titanium dinuclear complexes containing $\mathrm{Ti}=\mathrm{N}=\mathrm{Ti}$ fragments $(1.763(5)-1.878(7) \AA),{ }^{11 \mathrm{~d}, 12 \mathrm{~b}, 20}$ and substantially shorter than the $\mathrm{Ti}(2)-\mathrm{N}(1)$ separations $(2.137(2) \AA$ in 2 and 2.084(3) $\AA$ for 3). A plausible interpretation of the bonding in complexes $\mathbf{2}$ and $\mathbf{3}$ is illustrated in Scheme 2. The bonding system can be described by two resonance forms in valence bond theory terms involving one titanium-nitrogen(1) double bond within the flat ring containing the $\operatorname{Ti}(1), \operatorname{Ti}(3), \mathrm{N}(1)$, 
and N(13) atoms. The first of the contributing structure represents a double bond between the $\operatorname{Ti}(3)$ and $N(1)$ atoms with concomitant dative $N(13) \rightarrow \operatorname{Ti}(3)$ bond, whereas the second structure comprises $\operatorname{Ti}(1)=\mathrm{N}(1)$ and $\mathrm{N}(13) \rightarrow \operatorname{Ti}(1)$ units.

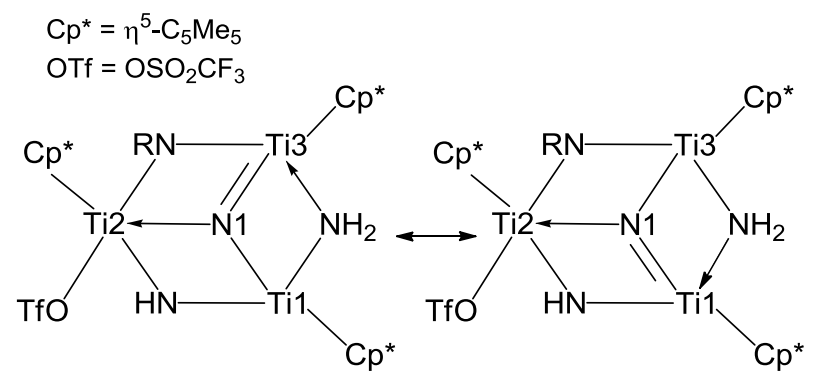

Scheme 2. Schematic representation of the bonding situation in complexes 2 and $\mathbf{3}$.

The triflato group is linked to titanium(2) with $\mathrm{Ti}(2)-\mathrm{O}(1)$ bond lengths of 2.172(2) $\AA$ in 2 and 2.157(3) $\AA$ for 3, which are longer than the Ti-O distances found in other titanium derivatives with terminal triflato ligands $\left(1.938(1)-2.142(3) \AA{ }^{2}{ }^{21}\right.$ The remaining oxygen atoms of the trifluoromethanesulfonato groups, $\mathrm{O}(2)$ and $\mathrm{O}(3)$, are involved in $\mathrm{N}-\mathrm{H} \cdots \mathrm{O}$ intramolecular hydrogen bonds with the endo hydrogen of the $\mu-\mathrm{NH}_{2}$ amido and the $\mu-\mathrm{NH}$ imido ligands (Figure 2, Table 3). Those interactions can be classified as weak according to the criteria on the donor-acceptor distances. ${ }^{22}$ In addition, complex $\mathbf{3}$ displays intermolecular hydrogen bonding interactions between the $\mathrm{O}(3)$ atom and the exo hydrogen of the $\mu-\mathrm{NH}_{2}$ amido ligand to result in molecules linked in pairs across a crystallographic symmetry center (Figure 2). 

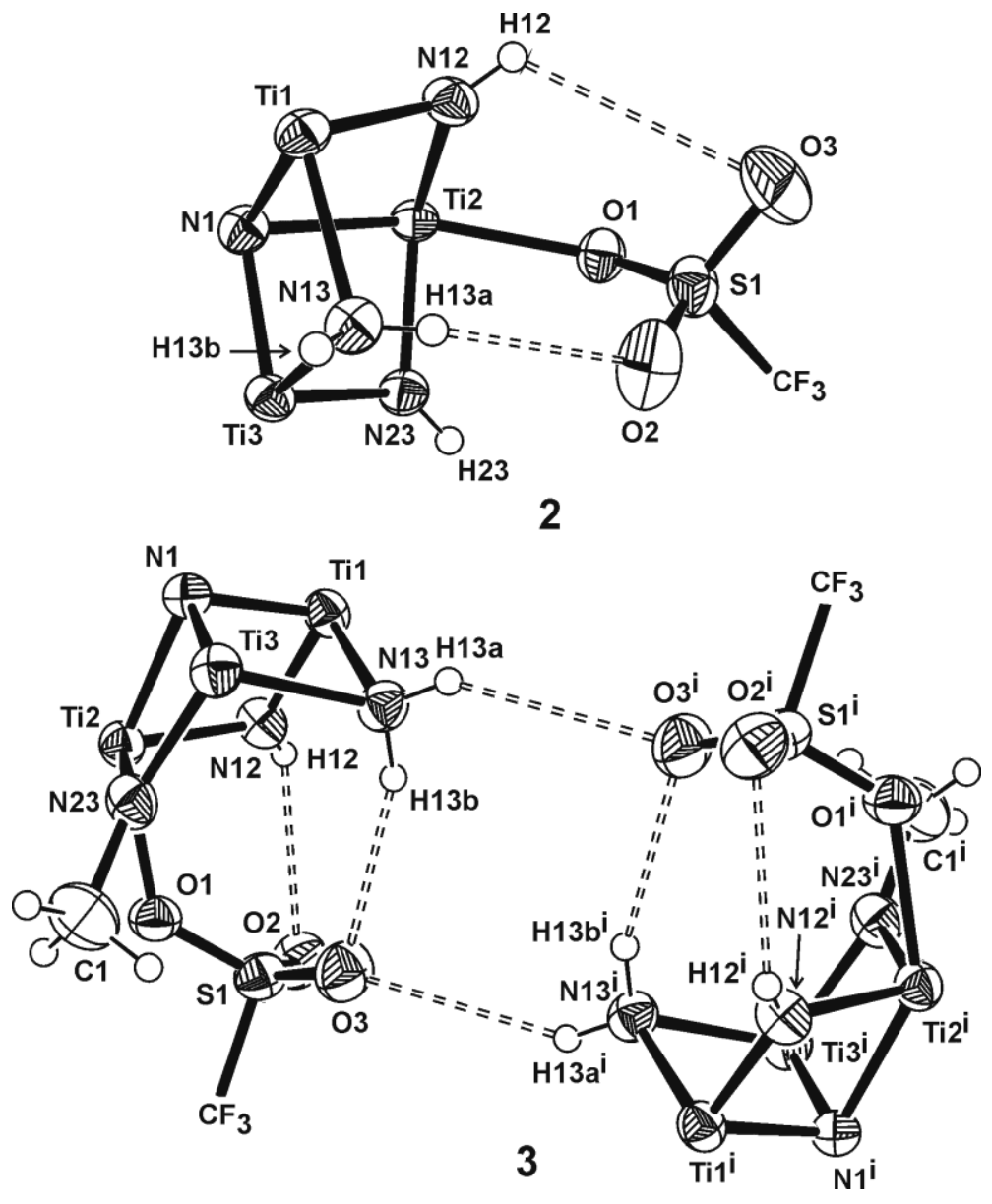

Figure 2. Simplified view of the intra- and intermolecular hydrogen bonding interactions present in complexes 2 and 3. Symmetry code: (i) $-\mathrm{x}, 2-\mathrm{y},-\mathrm{z}$.

Table 3. Relevant Hydrogen Bonds ${ }^{a}$ for Compounds 2 and 3.

\begin{tabular}{cllcc}
\hline & $\mathrm{D}-\mathrm{H} \cdots \mathrm{A}$ & $\mathrm{D} \cdots \mathrm{A} / \AA$ & $\mathrm{H} \cdots \mathrm{A} / \AA$ & $\mathrm{D}-\mathrm{H} \cdots \mathrm{A} /{ }^{\circ}$ \\
\hline \multirow{2}{*}{$\mathbf{N}$} & $\mathrm{N}(12)-\mathrm{H}(12) \cdots \mathrm{O}(3)$ & $3.574(5)$ & $3.15(4)$ & $118(3)$ \\
& $\mathrm{N}(13)-\mathrm{H}(13 \mathrm{a}) \cdots \mathrm{O}(2)$ & $3.198(4)$ & $2.45(4)$ & $164(4)$ \\
\hline \multirow{2}{*}{$\mathbf{3}$} & $\mathrm{N}(12)-\mathrm{H}(12) \cdots \mathrm{O}(2)$ & $3.130(4)$ & & \\
& $\mathrm{N}(13)-\mathrm{H}(13 \mathrm{a}) \cdots \mathrm{O}(3)$ & $3.417(6)$ & $2.54(5)$ & $159(4)$ \\
& $\mathrm{N}(13)-\mathrm{H}(13 \mathrm{~b}) \cdots \mathrm{O}(3) \mathrm{i}^{\mathrm{b}}$ & $3.576(6)$ & $2.81(4)$ & $146(3)$ \\
\hline${ }^{\mathrm{a}} \mathrm{A}=$ acceptor; $\mathrm{D}=$ donor. ${ }^{\mathrm{b}}$ Symmetry code: $(\mathrm{i})-\mathrm{x}, 2-\mathrm{y},-\mathrm{z}$. &
\end{tabular}


The IR spectra $(\mathrm{KBr})$ of compounds $\mathbf{2}$ and $\mathbf{3}$ show several bands in the $v_{\mathrm{NH}}$ region, between 3374 and $3250 \mathrm{~cm}^{-1}$, for the $\mathrm{NH}$ and $\mathrm{NH}_{2}$ ligands. In addition, the spectra of 2 and 3 reveal one absorption at 1578 and $1590 \mathrm{~cm}^{-1}$ respectively, assignable to the $\mathrm{NH}_{2}$ bending mode. ${ }^{23}$ Also the IR spectra show several strong absorptions in the range $1315-1011 \mathrm{~cm}^{-1}$ for the coordinated triflato ligands. ${ }^{24}$ Surprisingly, the ${ }^{1} \mathrm{H}$ and ${ }^{13} \mathrm{C}\left\{{ }^{1} \mathrm{H}\right\}$ NMR spectra of solutions of crystals of complexes $\mathbf{2}$ and $\mathbf{3}$ in benzene- $\mathrm{d}_{6}$ or chloroform- $\mathrm{d}_{1}$ at room temperature are different of those expected from their solid-state structures. Thus, the ${ }^{1} \mathrm{H}$ NMR spectra of 2 show only one broad singlet for the $\eta^{5}-\mathrm{C}_{5} \mathrm{Me}_{5}$ ligands, instead of the two 2:1 signals expected from the nearly $C_{s}$ symmetry in the solid-state. Furthermore, while the ${ }^{1} \mathrm{H}$ NMR spectra of $\mathbf{3}$ reveal the resonance signals predicted for the $C_{1}$ symmetry determined in the crystal structure, the resonances for two $\eta^{5}-\mathrm{C}_{5} \mathrm{Me}_{5}$ ligands and those assigned to the $\mathrm{NH}$ and $\mathrm{NH}_{2}$ groups are broad. ${ }^{16}$ These NMR data suggest a dynamic exchange process in solution, and ${ }^{1} \mathrm{H}$ NMR spectra of dichloromethane- $\mathrm{d}_{2}$ solutions were taken at low temperatures in a $500 \mathrm{MHz}$ spectrometer. Indeed, the ${ }^{1} \mathrm{H}$ NMR spectrum of 2 at $-50{ }^{\circ} \mathrm{C}$ is consistent with a $C_{\mathrm{s}}$ symmetric structure in solution, while the spectrum of $\mathbf{3}$ at $-30{ }^{\circ} \mathrm{C}$ reveals sharp resonances for the $\eta^{5}-\mathrm{C}_{5} \mathrm{Me}_{5}$ and $\mu-\mathrm{NH}_{2}$ ligands.

The dynamic behavior may be the result of the proton transfer from the $\mathrm{NH}_{2}$ group to the hydrogen-bonded triflato ligand and generation of HOTf, which then delivers that proton to the $\mathrm{NH}$ imido group with concomitant coordination of the triflato ligand at the opposite titanium atom. Such rapid exchange would create time-averaged $C_{3 \mathrm{v}}$ symmetry for 2 and $C_{\text {s }}$ symmetry for 3 by ${ }^{1} \mathrm{H}$ NMR spectroscopy at high temperatures. Complete dissociation of HOTf can be ruled out because addition of small amounts of $\mathbf{1}$ to solutions of compounds $\mathbf{2}$ or $\mathbf{3}$ does not affect the exchange process and the activation parameters 
remain unaltered. A plausible mechanism for the dynamic event is shown in Scheme 3, which is similar to that studied in detail by Limbach and co-workers for the proton exchange process in diaryltriazenes catalyzed by the presence of bases in the medium. ${ }^{25} \mathrm{In}$ our complexes the function of the basic catalyst could be played by the triflato ligand, which is prone to dissociate from the metal centers. ${ }^{26}$

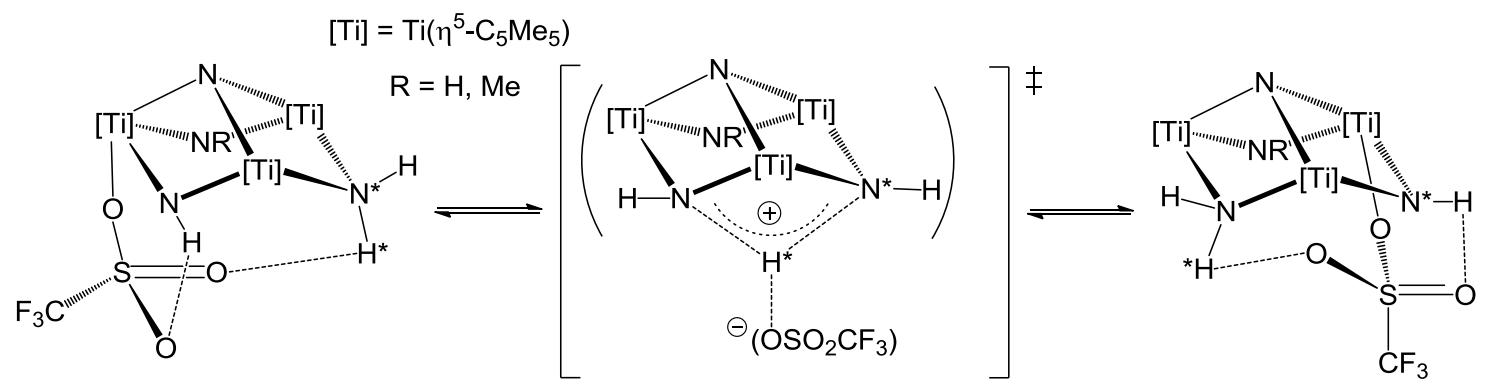

Scheme 3. Proposed fluxional process for complexes $\mathbf{2}$ and $\mathbf{3}$.

The kinetic parameters (Table 4) of the observed process were calculated on the basis of dynamic ${ }^{1} \mathrm{H}$ NMR spectroscopy data with line shape analysis of the $\eta^{5}-\mathrm{C}_{5} \mathrm{Me}_{5}$ resonances using the gNMR program (see Tables S1-S4 and Figures S1-S8 in the Supporting Information). ${ }^{27}$ The results disagree with those expected for an intramolecular nondissociative mechanism since the $\log A(8.5-9.8)$ and $\Delta \mathrm{S}^{\ddagger}$ (between -7.7 and -21.3 e.u.) values differ from the usual parameters for that type of processes ( $\log A=12-14$ and $\Delta \mathrm{S}^{*} \approx 0$ e.u.). ${ }^{28}$ However, in accord with the highly negative values of $\Delta \mathrm{S}^{\ddagger}$, the reduction of the $\log \mathrm{A}$ in several units could be related to the organization of the solvent molecules due to the participation of zwitterionic species in the exchange process, ${ }^{25 b, 29}$ as shown in Scheme 3. Indeed, when the kinetic parameters of complex 2 are obtained in toluene- $\mathrm{d}_{8}$, the entropy of activation falls to -7.7 e.u. in agreement with the expected for a less polar 
solvent. Importantly, the $\Delta \mathrm{G}^{\ddagger}$ values calculated in both solvents are comparable, suggesting that the exchange process is the same and the entropy differences are compensated by the enthalpy associated. ${ }^{29}$

Table 4. Activation Parameters for the Exchange of $\eta^{5}-\mathrm{C}_{5} \mathrm{Me}_{5}$ Resonances in Complexes 2 and 3.

\begin{tabular}{llllll}
\hline Compound & $\log \mathrm{A}$ & $\begin{array}{l}\mathrm{E}_{\mathrm{a}} \\
{\left[\mathrm{kcal} \mathrm{mol}{ }^{-1}\right]}\end{array}$ & $\begin{array}{l}\Delta \mathrm{H}^{\ddagger} \\
{\left[\mathrm{kcal} \mathrm{mol}^{-1}\right]}\end{array}$ & $\begin{array}{l}\Delta \mathrm{S}^{\ddagger} \\
{\left[\mathrm{cal} \mathrm{mol}^{-1} \mathrm{~K}^{-1}\right]}\end{array}$ & $\begin{array}{l}\Delta \mathrm{G}^{\ddagger 298 \mathrm{~K}} \\
{\left[\mathrm{kcal} \mathrm{mol}^{-1}\right]}\end{array}$ \\
\hline $\mathbf{2}^{\mathrm{a}}$ & $8.5 \pm 1.2$ & $8.4 \pm 0.3$ & $7.9 \pm 0.3$ & $-21.3 \pm 1.0$ & 14.2 \\
$\mathbf{2}^{\mathrm{b}}$ & $9.8 \pm 0.8$ & $9.7 \pm 0.2$ & $9.2 \pm 0.2$ & $-15.6 \pm 0.7$ & 13.9 \\
$\mathbf{2}^{\mathrm{c}}$ & $8.5 \pm 2.1$ & $8.4 \pm 0.5$ & $11.9 \pm 0.5$ & $-7.7 \pm 1.8$ & 14.2 \\
$\mathbf{3}^{\mathrm{a}}$ & $8.9 \pm 1.7$ & $9.5 \pm 0.4$ & $8.9 \pm 0.4$ & $-19.7 \pm 1.5$ & 14.8 \\
\hline${ }^{\mathrm{a}} \mathrm{CD}_{2} \mathrm{Cl}_{2,} \sim 1.6 \times 10^{-2} \mathrm{M} .^{\mathrm{b}} \mathrm{CD}_{2} \mathrm{Cl}_{2}, \sim 5.3 \times 10^{-3} \mathrm{M}^{\mathrm{c}}{ }^{\mathrm{C}} \mathrm{C}_{7} \mathrm{D}_{8}, \sim 1.1 \times 10^{-2} \mathrm{M}$. &
\end{tabular}

An analogue proton migration within the trinuclear titanium system could explain the formation of complex 3 in the treatment of $\mathbf{1}$ with one equivalent of MeOTf (Scheme 4). Monitoring by NMR spectroscopy the reaction course in benzene- $\mathrm{d}_{6}$ showed that the alkylation occurs at the $\mathrm{NH}$ imido ligands of $\mathbf{1}$ to produce the methylamido derivative $\left[\mathrm{Ti}_{3}\left(\eta^{5}-\mathrm{C}_{5} \mathrm{Me}_{5}\right)_{3}\left(\mu_{3}-\mathrm{N}\right)(\mu-\mathrm{NH})_{2}(\mu-\mathrm{NHMe})(\mathrm{OTf})\right](\mathbf{4}) .{ }^{16}$ Compound 4 readily rearranges at room temperature to form complex 3 (conversion is ca. $25 \%$ after 2 h, and $100 \%$ after 24 h). Thus, complex 4 could not be obtained in a pure form and was only characterized by ${ }^{1} \mathrm{H}$, ${ }^{13} \mathrm{C}\left\{{ }^{1} \mathrm{H}\right\}$ and ${ }^{19} \mathrm{~F}$ NMR spectroscopy. The NMR data are consistent with a $C_{\mathrm{s}}$ symmetric structure with the methylamido and triflato ligands in the mirror plane of the molecule. NOESY-1D experiments on a solution of 4 in benzene- $\mathrm{d}_{6}$ provided evidence for the endo position of the methyl group for the $\mu$-NHMe ligand. The rotation of the amido ligand in 
complex 4 could place the methyl fragment in the exo position while the new endo hydrogen interacts with the triflato ligand. From this undetected intermediate, the migration of the proton from the NHMe amido group to the NH imido ligands, assisted by the triflato moiety, would lead to compound $\mathbf{3}$.

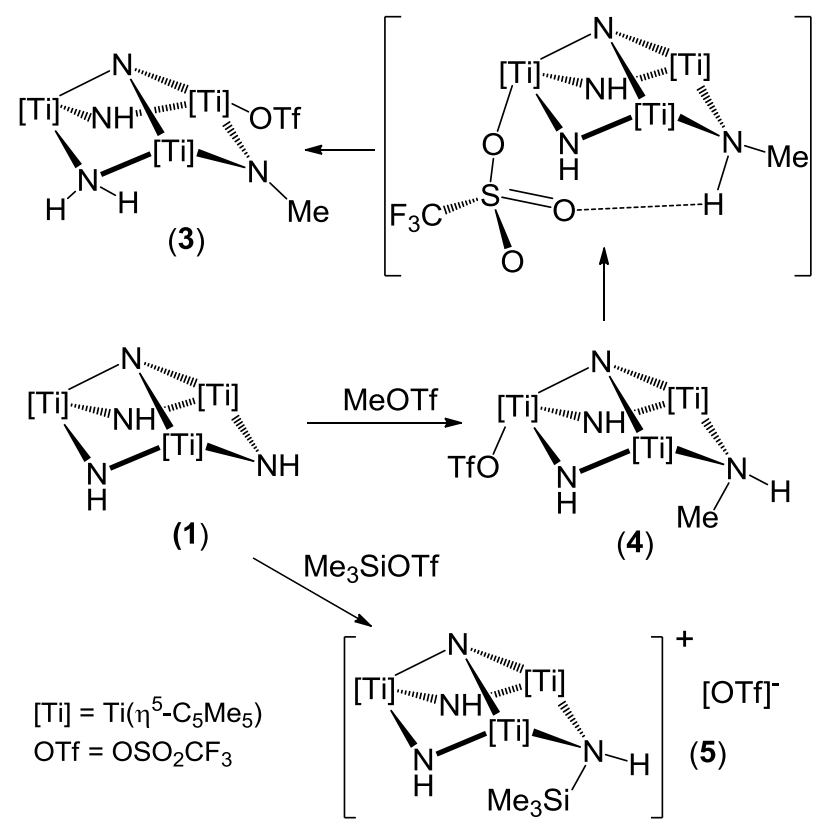

Scheme 4. Reaction of 1 with one equivalent of ROTf $\left(\mathrm{R}=\mathrm{Me}, \mathrm{SiMe}_{3}\right)$.

To isolate a stable compound with a structure similar to $\mathbf{4}$, we studied the reaction of $\left[\left\{\mathrm{Ti}\left(\eta^{5}-\mathrm{C}_{5} \mathrm{Me}_{5}\right)(\mu-\mathrm{NH})\right\}_{3}\left(\mu_{3}-\mathrm{N}\right)\right](\mathbf{1})$ with an electrophilic reagent ROTf bearing a bulkier $\mathrm{R}$ fragment. Thus, the treatment of $\mathbf{1}$ with 1 equiv of trimethylsilyl triflate in toluene at room temperature afforded the precipitation of the ionic complex $\left[\mathrm{Ti}_{3}\left(\eta^{5}-\mathrm{C}_{5} \mathrm{Me}_{5}\right)_{3}\left(\mu \mu_{3}-\mathrm{N}\right)(\mu-\right.$ $\left.\mathrm{NH})_{2}\left(\mu-\mathrm{NHSiMe}_{3}\right)\right]\left[\mathrm{O}_{3} \mathrm{SCF}_{3}\right](\mathbf{5})$ (Scheme 4). This compound was obtained in $88 \%$ yield as an orange solid, which is poorly soluble in toluene or benzene but exhibits a good solubility in halogenated solvents. Solutions of $\mathbf{5}$ in chloroform- $\mathrm{d}_{1}$ slowly decompose within several 
days at room temperature to give free trimethylsilylamine and several unidentified products as determined by ${ }^{1} \mathrm{H}$ NMR spectroscopy. The IR spectrum $(\mathrm{KBr})$ of 5 shows only one broad band centered at $3271 \mathrm{~cm}^{-1}$ for the $v_{\mathrm{NH}}$ vibrations and several strong absorptions in the range $1252-1031 \mathrm{~cm}^{-1}$ for the triflate group. ${ }^{24}$ In particular, the observed $v_{\mathrm{as}}\left(\mathrm{SO}_{3}\right)$ band at $1252 \mathrm{~cm}^{-1}$ is typical for the free trifluoromethanesulfonate anion. ${ }^{24 b}$ The ${ }^{1} \mathrm{H}$ NMR spectrum in chloroform- $\mathrm{d}_{1}$ at room temperature reveals two resonances for $\eta^{5}-\mathrm{C}_{5} \mathrm{Me}_{5}$ ligands in a 2:1 ratio, two broad signals for the $\mu-\mathrm{NH}$ and $\mu-\mathrm{NHSiMe}$ protons and a highfield singlet for the trimethylsilyl group. These data agree with a $C_{s}$ symmetric structure in solution, which is also consistent with the ${ }^{13} \mathrm{C}\left\{{ }^{1} \mathrm{H}\right\}$ NMR spectrum. NOESY-1D experiments confirmed the endo disposition of the trimethylsilyl group in a fashion similar to the methyl fragment in $\mathbf{4}$, but the greater steric bulk of the $\mathrm{SiMe}_{3}$ group precludes the coordination of the triflate to yield $\mathbf{5}$ as an ion pair, at least in the solid-state.

The X-ray crystal structure of $\mathbf{5}$ shows each trifluoromethanesulfonate anion linking through hydrogen bonding interactions two trinuclear titanium cations to give polymeric zigzag chains (see Figure S9 in the Supporting Information). Thus, each triflate anion establishes a hydrogen bond between the $\mathrm{O}(1)$ atom and the $\mathrm{NH}$ ligand of one cation $(\mathrm{N}(13) \cdots \mathrm{O}(1)=3.322(1) \AA)$, while $\mathrm{O}(3)$ interacts with the $\mathrm{NH}$ group of a contiguous cation $(\mathrm{N}(23) \mathrm{b} \cdots \mathrm{O}(3)=3.311(1) \AA)$. The cationic fragment of compound 5 is presented in Figure 3, while selected distances and angles are given in Table 5. 


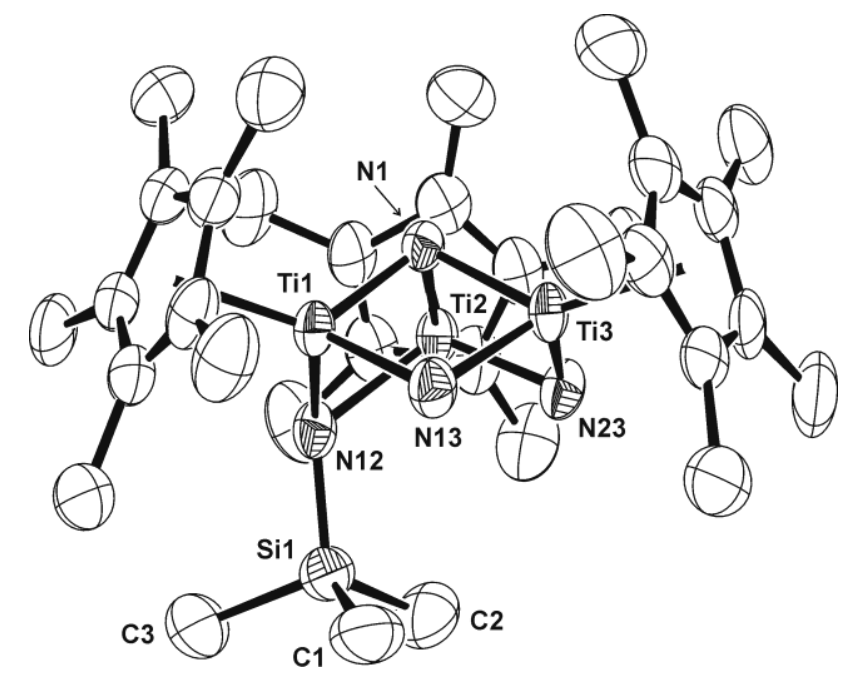

Figure 3. Perspective view of the cationic fragment of complex 5 (thermal ellipsoids at the $50 \%$ probability level). Hydrogen atoms are omitted for clarity.

Table 5. Selected Lengths ( $\mathrm{A})$ and Angles (deg) for Complexes 5 and 6.

\begin{tabular}{lcclrr}
\hline Lengths & \multicolumn{1}{c}{$\mathbf{6}$} & $\mathbf{6}$ & Angles & \multicolumn{1}{c}{$\mathbf{5}$} & \multicolumn{1}{c}{$\mathbf{6}$} \\
\hline $\operatorname{Ti}(1)-\mathrm{N}(1)$ & $1.921(4)$ & $1.878(2)$ & $\mathrm{N}(1)-\mathrm{Ti}(1)-\mathrm{N}(12)$ & $85.9(2)$ & $86.8(1)$ \\
$\operatorname{Ti}(1)-\mathrm{N}(12)$ & $2.121(5)$ & $2.105(2)$ & $\mathrm{N}(1)-\mathrm{Ti}(1)-\mathrm{N}(13)$ & $87.3(2)$ & $89.1(1)$ \\
$\operatorname{Ti}(1)-\mathrm{N}(13)$ & $1.866(4)$ & $1.817(2)$ & $\mathrm{N}(12)-\mathrm{Ti}(1)-\mathrm{N}(13)$ & $103.3(2)$ & $103.6(1)$ \\
$\operatorname{Ti}(2)-\mathrm{N}(1)$ & $1.917(5)$ & $1.914(2)$ & $\mathrm{N}(1)-\mathrm{Ti}(2)-\mathrm{N}(12)$ & $86.3(2)$ & $85.9(1)$ \\
$\operatorname{Ti}(2)-\mathrm{N}(12)$ & $2.111(5)$ & $2.103(2)$ & $\mathrm{N}(1)-\mathrm{Ti}(2)-\mathrm{N}(23)$ & $88.0(2)$ & $88.4(1)$ \\
$\operatorname{Ti}(2)-\mathrm{N}(23)$ & $1.868(4)$ & $1.793(3)$ & $\mathrm{N}(12)-\mathrm{Ti}(2)-\mathrm{N}(23)$ & $105.2(2)$ & $103.8(1)$ \\
$\operatorname{Ti}(3)-\mathrm{N}(1)$ & $1.938(4)$ & $1.957(2)$ & $\mathrm{N}(1)-\mathrm{Ti}(3)-\mathrm{N}(13)$ & $84.0(2)$ & $83.8(1)$ \\
$\operatorname{Ti}(3)-\mathrm{N}(13)$ & $1.971(5)$ & $1.923(2)$ & $\mathrm{N}(1)-\mathrm{Ti}(3)-\mathrm{N}(23)$ & $84.4(2)$ & $84.4(1)$ \\
$\operatorname{Ti}(3)-\mathrm{N}(23)$ & $1.978(5)$ & $1.892(2)$ & $\mathrm{N}(13)-\mathrm{Ti}(3)-\mathrm{N}(23)$ & $110.4(2)$ & $109.9(1)$ \\
$\mathrm{N}(12)-\mathrm{Si}(1)$ & $1.808(5)$ & $1.761(2)$ & $\mathrm{Ti}(1)-\mathrm{N}(1)-\mathrm{Ti}(2)$ & $99.8(2)$ & $99.6(1)$ \\
$\operatorname{Ti}(1) \cdots \operatorname{Ti}(2)$ & $2.935(2)$ & $2.896(1)$ & $\mathrm{Ti}(1)-\mathrm{N}(1)-\mathrm{Ti}(3)$ & $93.8(2)$ & $91.7(1)$ \\
$\operatorname{Ti}(1) \cdots \operatorname{Ti}(3)$ & $2.818(1)$ & $2.753(2)$ & $\mathrm{Ti}(2)-\mathrm{N}(1)-\mathrm{Ti}(3)$ & $93.3(2)$ & $90.4(1)$ \\
$\operatorname{Ti}(2) \cdots \operatorname{Ti}(3)$ & $2.804(1)$ & $2.746(1)$ & $\mathrm{Ti}(1)-\mathrm{N}(12)-\mathrm{Ti}(2)$ & $87.8(2)$ & $87.0(1)$ \\
& & & $\mathrm{Ti}(1)-\mathrm{N}(12)-\mathrm{Si}(1)$ & $124.0(2)$ & $124.5(1)$ \\
& & & $\mathrm{Ti}(2)-\mathrm{N}(12)-\mathrm{Si}(1)$ & $120.6(2)$ & $121.0(1)$ \\
& & & $\mathrm{Ti}(1)-\mathrm{N}(13)-\mathrm{Ti}(3)$ & $94.5(2)$ & $94.7(1)$ \\
& & & & $93.5(2)$ & $96.3(1)$ \\
\hline & & & & &
\end{tabular}


The cation of 5 contains a $\left[\mathrm{Ti}_{3} \mathrm{~N}_{3}\right]$ six-membered ring that adopts a chair conformation similar to that of $\mathbf{1},{ }^{12 a}$ and those described above for complexes $\mathbf{2}$ and $\mathbf{3}$. In contrast to compounds $\mathbf{2}$ and $\mathbf{3}$, the cationic fragment of $\mathbf{5}$ shows the nitrido atom $\mathrm{N}(1)$ bridging the titanium atoms with the three $\mathrm{Ti}-\mathrm{N}(1)$ distances within a narrow range, 1.917(5)-1.938(4) $\AA$, which compares well with that determined in complex 1 (Ti-N(1) 1.912(1) $\AA$ ). The $\mathrm{NHSiMe}_{3}$ amido group in 5 bridges the $\operatorname{Ti}(1)$ and $\mathrm{Ti}(2)$ atoms in a symmetric fashion with $\mathrm{Ti}-\mathrm{N}(12)$ bond lengths, $2.111(5)$ and $2.121(5) \AA$, very similar to the Ti-N separations found for the $\mathrm{NH}_{2}$ amido ligand in complexes 2 and 3. Each $\mathrm{NH}$ imido ligand of 5 bridges asymmetrically two titanium atoms with $\mathrm{Ti}(1)-\mathrm{N}(13)$ and $\operatorname{Ti}(2)-\mathrm{N}(23)$ bond lengths, $1.866(4)$ and $1.868(4) \AA$, clearly shorter than those found with the $\operatorname{Ti}(3)$ atom, $\operatorname{Ti}(3)-\mathrm{N}(13) 1.971(5)$ and $\operatorname{Ti}(3)-\mathrm{N}(23) 1.978(5) \AA$. Therefore, the solidstate structure of the cation of $\mathbf{5}$ is very close to the $C_{\mathrm{s}}$ symmetry determined in solution by NMR spectroscopy. A plausible interpretation of the bonding in the trinuclear cation is illustrated in the left side of Scheme 5. The bonding system can be described by two resonance forms in valence bond theory terms containing the positive charge on titanium(1) or titanium(2) atoms. 

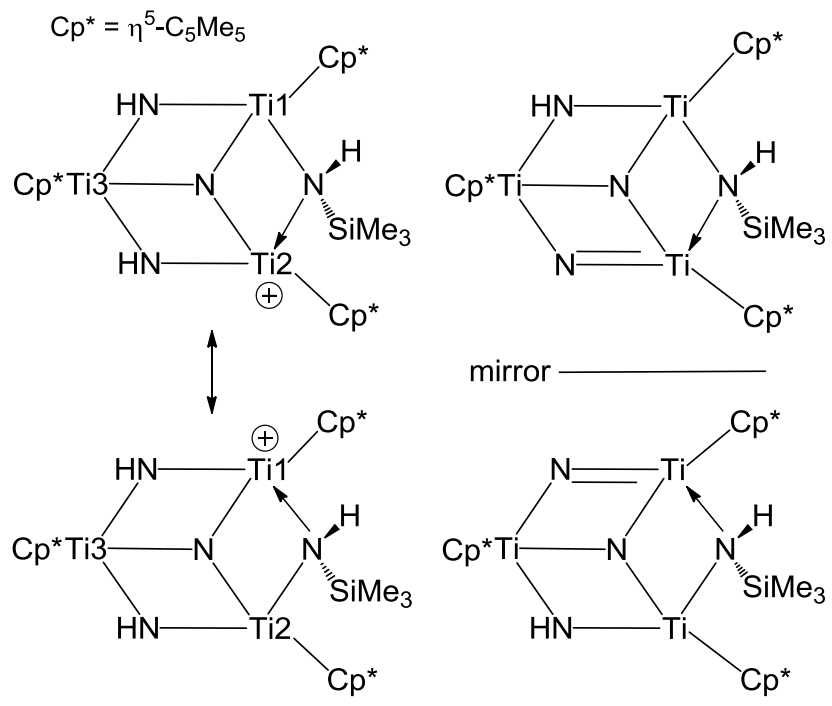

cation of 5

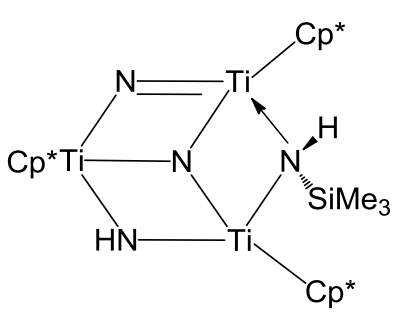

$-\mathrm{H}^{+} \longrightarrow(6)$

Scheme 5. Schematic representation of the bonding situation in the cation of $\mathbf{5}$ and complex 6.

The treatment of $\mathbf{5}$ with 1 equiv of potassium bis(trimethylsilyl)amide in toluene at room temperature leads to the molecular complex $\left[\mathrm{Ti}_{3}\left(\eta^{5}-\mathrm{C}_{5} \mathrm{Me}_{5}\right)_{3}\left(\mu_{3}-\mathrm{N}\right)(\mu-\mathrm{N})(\mu-\mathrm{NH})(\mu-\right.$ $\left.\left.\mathrm{NHSiMe}_{3}\right)\right](6), \mathrm{NH}\left(\mathrm{SiMe}_{3}\right)_{2}$, and KOTf (Scheme 6). Compound 6 was isolated as a red solid in $69 \%$ yield if the reaction and subsequent workup were performed within $1 \mathrm{~h}$. Reactions carried out at room temperature for longer periods of time afforded mixtures of compound 6 and the trimethylsilylimido derivative $\left[\mathrm{Ti}_{3}\left(\eta^{5}-\mathrm{C}_{5} \mathrm{Me}_{5}\right)_{3}\left(\mu_{3}-\mathrm{N}\right)(\mu-\mathrm{NH})_{2}(\mu-\right.$ $\mathrm{NSiMe}_{3}$ )] (7). Indeed, complex 7 was isolated as an orange solid in $69 \%$ yield if the reaction mixture of 5 and $\left[\mathrm{K}\left\{\mathrm{N}\left(\mathrm{SiMe}_{3}\right)_{2}\right\}\right]$ in toluene was heated at $85{ }^{\circ} \mathrm{C}$ for $24 \mathrm{~h}$. Compound 7 has been previously obtained by treatment of $\left[\left\{\mathrm{Li}\left(\mu_{4}-\mathrm{N}\right)\left(\mu_{3}-\mathrm{NH}\right)_{2} \mathrm{Ti}_{3}\left(\eta^{5}-\right.\right.\right.$ $\left.\left.\left.\mathrm{C}_{5} \mathrm{Me}_{5}\right)_{3}\left(\mu_{3}-\mathrm{N}\right)\right\}_{2}\right]$ with $\left[\mathrm{SiClMe}_{3}\right]$ in toluene at room temperature. ${ }^{17}$ 


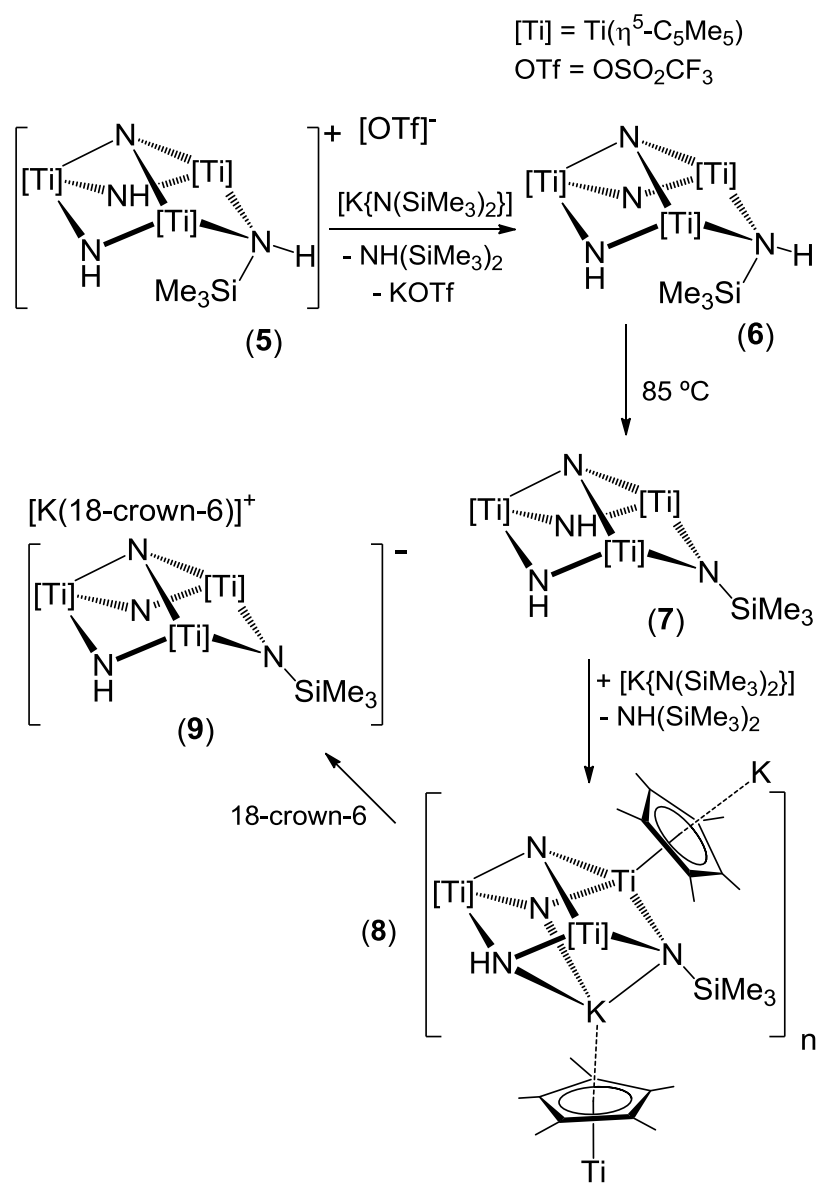

Scheme 6. Reactions with $\left[\mathrm{K}\left\{\mathrm{N}\left(\mathrm{SiMe}_{3}\right)_{2}\right\}\right]$.

Compound 6 was characterized by spectroscopic and analytical methods, as well as by an X-ray crystal structure determination. The IR spectrum $(\mathrm{KBr})$ of $\mathbf{6}$ shows two $\mathrm{v}_{\mathrm{NH}}$ vibrations at 3353 and $3273 \mathrm{~cm}^{-1}$ for the $\mathrm{NH}$ and $\mathrm{NHSiMe}_{3}$ ligands. The ${ }^{1} \mathrm{H}$ NMR spectrum of 6 in benzene- $d_{6}$ at room temperature reveals three resonance signals for the $\eta^{5}-\mathrm{C}_{5} \mathrm{Me}_{5}$ ligands in a 1:1:1 ratio, one broad signal for one $\mu-\mathrm{NH}$ imido group and those assigned to the $\mathrm{NHSiMe}_{3}$ trimethylsilylamido ligand. The NMR data of $\mathbf{6}$ are consistent with a $C_{1}$ symmetric structure in solution, in contrast to the $C_{\mathrm{s}}$ symmetry observed in the NMR spectra of $7 .^{17}$ The solid-state structure of 6 is presented in Figure 4, while selected distances and angles are given in Table 5. The $\left[\mathrm{Ti}_{3} \mathrm{~N}_{4}\right]$ core of $\mathbf{6}$ is similar to that described 
above for the cation of complex $\mathbf{5}$. Thus, the nitrido ligand $\mathrm{N}(1)$ bridges the three titanium centers with $\mathrm{Ti}-\mathrm{N}(1)$ bond lengths in the range $1.878(2)-1.957(2) \AA$, and the amido $\mathrm{NHSiMe}_{3}$ ligand is bonded to the $\mathrm{Ti}(1)$ and $\mathrm{Ti}(2)$ atoms with distances $\mathrm{Ti}(1)-\mathrm{N}(12)$ and $\mathrm{Ti}(2)-\mathrm{N}(12)$ of $2.105(2)$ and $2.103(2) \AA$, respectively. While these bond lengths are very close to those observed in 5, complex $\mathbf{6}$ shows a shortening of the $\mathrm{Ti}-\mathrm{N}$ distances associated with the $\mathrm{N}(13)$ and $\mathrm{N}(23)$ atoms as expected for the deprotonation of one $\mathrm{NH}$ imido group to yield a $\mu-\mathrm{N}$ nitrido ligand. The $\operatorname{Ti}(1)-\mathrm{N}(13)$ and $\operatorname{Ti}(2)-\mathrm{N}(23)$ bond lengths, 1.817(2) and 1.793(2) $\AA$ respectively, are about $0.1 \AA$ shorter than the titanium-nitrogen distances associated to the titanium(3) atom, $\operatorname{Ti}(3)-\mathrm{N}(13) 1.923 \AA$ and $\operatorname{Ti}(3)-\mathrm{N}(23)$ 1.892(2) $\AA$. A plausible interpretation of these distances, and the nearly $C_{\mathrm{s}}$ symmetric structure of $\mathbf{6}$ determined by X-ray crystallography, is the existence of an equimolecular mixture of the two enantiomers originated from proton abstraction of complex $\mathbf{5}$ as shown in the right side of Scheme 5.

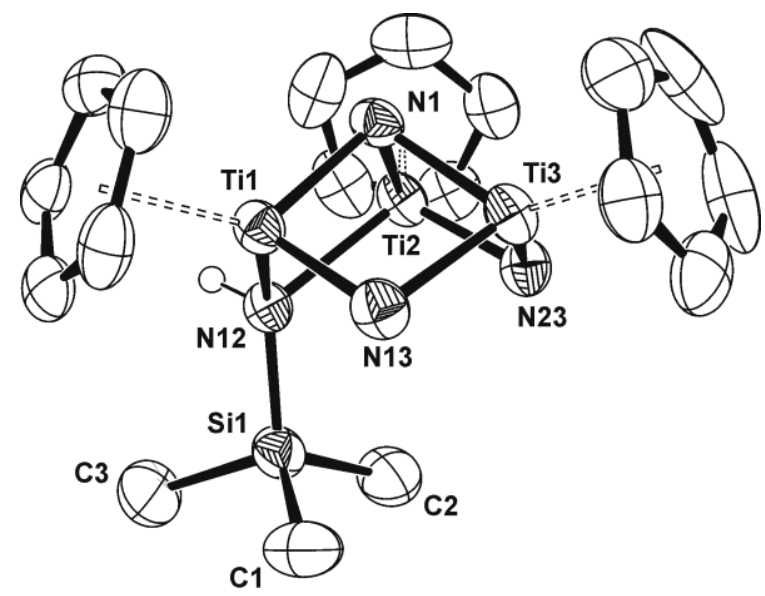

Figure 4. Perspective view of complex 6 (thermal ellipsoids at the $50 \%$ probability level). Methyl groups of the pentamethylcyclopentadienyl ligands and hydrogen atoms of the imido groups are omitted for clarity. 
The conversion of $\mathbf{6}$ to complex $\mathbf{7}$ in solution at room temperature was monitored by ${ }^{1} \mathrm{H}$ NMR spectroscopy. Once isolated 6 in a pure form, the rearrangement is slow in benzene- $\mathrm{d}_{6}$ solution (ca. $10 \%$ after 3 days). While addition of tetrahydrofuran (4 equiv) to a benzene- $\mathrm{d}_{6}$ solution of $\mathbf{6}$ does not affect the reaction rate, the presence of residual free $\mathrm{NH}\left(\mathrm{SiMe}_{3}\right)_{2}$ in the solution produces a significant enhancement of the transformation. Furthermore, upon dissolving 6 in chloroform- $\mathrm{d}_{1}$ there is an immediate color change from red to orange and the ${ }^{1} \mathrm{H}$ NMR spectrum shows resonances assigned to 7. Complete consumption of 6 in chloroform- $\mathrm{d}_{1}$ occurs within $24 \mathrm{~h}$ to give complex 7 , with partial incorporation of deuterium at the $\mu-\mathrm{NH}$ ligands, along with minor amounts $(\approx 7 \%)$ of compound 1. In view of these results, it appears that the rearrangement is catalyzed by a Brønsted acid $\mathrm{HA}$, such as $\mathrm{NH}\left(\mathrm{SiMe}_{3}\right)_{2}$ or $\mathrm{CHCl}_{3}$, which transfers the proton to the $\mu-\mathrm{N}$ ligand of 6 and subsequently its conjugate base $\mathrm{A}^{-}$accepts the proton from the $\mu-\mathrm{NHSiMe}_{3}$ amido ligand to generate 7 .

The reaction of 5 with 2 equiv of potassium bis(trimethylsilyl)amide in toluene at 85 ${ }^{\circ} \mathrm{C}$ or the treatment of 7 with 1 equiv of $\left[\mathrm{K}\left\{\mathrm{N}\left(\mathrm{SiMe}_{3}\right)_{2}\right\}\right]$ at room temperature afforded the potassium derivative $\left[\mathrm{K}\left\{\left(\mu_{3}-\mathrm{N}\right)\left(\mu_{3}-\mathrm{NH}\right)\left(\mu_{3}-\mathrm{NSiMe}_{3}\right) \mathrm{Ti}_{3}\left(\eta^{5}-\mathrm{C}_{5} \mathrm{Me}_{5}\right)_{3}\left(\mu_{3}-\mathrm{N}\right)\right\}\right]$ (8) (Scheme 6). Compound $\mathbf{8}$ was isolated in $89 \%$ yield as a red solid, which is very soluble in benzene or toluene suggesting a molecular structure in solution. ${ }^{1} \mathrm{H}$ and ${ }^{13} \mathrm{C}\left\{{ }^{1} \mathrm{H}\right\}$ NMR spectra in benzene- $\mathrm{d}_{6}$ or pyridine- $\mathrm{d}_{5}$ show resonances for three different $\eta^{5}-\mathrm{C}_{5} \mathrm{Me} \mathrm{e}_{5}$ ligands and are consistent with a $C_{1}$ symmetric structure in solution. The NMR data could also agree with an edge-linked double-cube structure similar to those documented in alkali metal derivatives $\left[\left\{\mathrm{M}\left(\mu_{4}-\mathrm{N}\right)\left(\mu_{3}-\mathrm{NH}\right)_{2} \mathrm{Ti}_{3}\left(\eta^{5}-\mathrm{C}_{5} \mathrm{Me}_{5}\right)_{3}\left(\mu_{3}-\mathrm{N}\right)\right\}_{2}\right](\mathrm{M}=\mathrm{Li}, \mathrm{Na}, \mathrm{K}, \mathrm{Rb}, \mathrm{Cs}) .{ }^{17,30}$ However, in contrast to those species which are only soluble in pyridine, the high solubility 
of $\mathbf{8}$ in aromatic hydrocarbon solvents suggests a different structure. The solid-state structure of $\mathbf{8}$ determined by X-ray diffraction consists of polymeric zigzag chains made up of cube-type $\left[\mathrm{K}\left\{\left(\mu_{3}-\mathrm{N}\right)\left(\mu_{3}-\mathrm{NH}\right)\left(\mu_{3}-\mathrm{NSiMe}_{3}\right) \mathrm{Ti}_{3}\left(\eta^{5}-\mathrm{C}_{5} \mathrm{Me}_{5}\right)_{3}\left(\mu_{3}-\mathrm{N}\right)\right\}\right]$ units with the potassium atom linked to the contiguous molecule through a $\eta^{5}-\mathrm{C}_{5} \mathrm{Me}_{5}$ ligand (Figure 5). Compound $\mathbf{8}$ crystallized in the centrosymmetric $P 2_{1} / \mathrm{c}$ space group and the crystal lattice shows a regular alternation of the two enantiomers in neighboring chains.

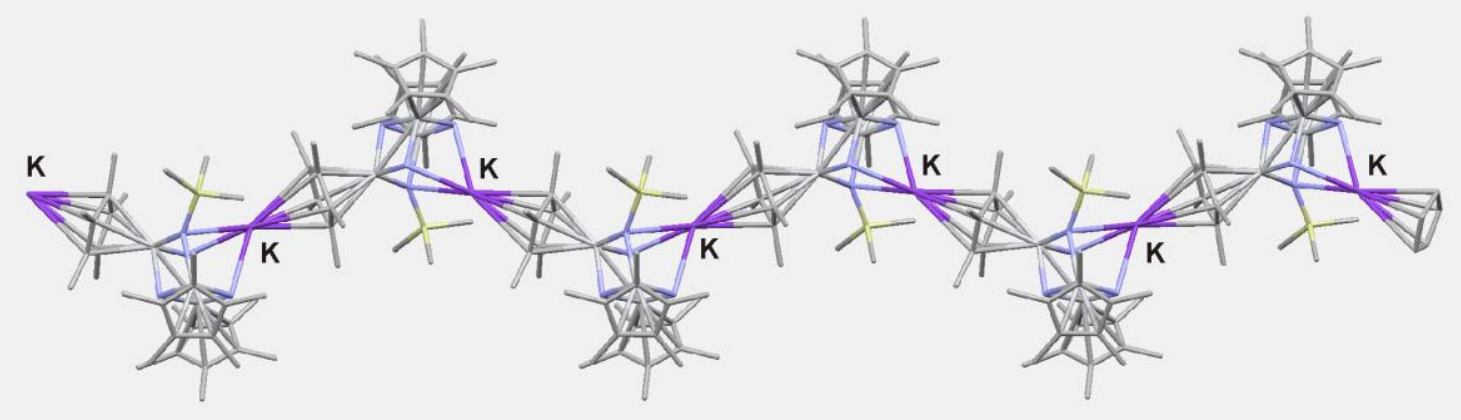

Figure 5. Perspective view of the polymeric chain of $\mathbf{8}$. Hydrogen atoms are omitted for clarity.

A portion of the polymeric chain of compound $\mathbf{8}$ is shown in Figure 6, while selected distances and angles are given in Table 6 . The crystal structure contains distorted $\left[\mathrm{KTi}_{3} \mathrm{~N}_{4}\right]$ cube-type cores with the metalloligands $\left[\left(\mu_{3}-\mathrm{N}\right)\left(\mu_{3}-\mathrm{NH}\right)\left(\mu_{3}-\mathrm{NSiMe}_{3}\right) \mathrm{Ti}_{3}\left(\eta^{5}-\mathrm{C}_{5} \mathrm{Me}_{5}\right)_{3}\left(\mu_{3}-\mathrm{N}\right)\right]$ coordinating in a tripodal fashion to the potassium centers. In addition, the alkali metal atoms are bonded to the five carbon atoms of the $\eta^{5}-\mathrm{C}_{5} \mathrm{Me}_{5}$ ligand linked to the titanium(1) atoms of a contiguous molecule. If the centroid $\mathrm{Cm}(1)$ of these pentamethylcyclopentadienyl ligands are considered, the coordination sphere about the 
potassium atoms may be described as distorted tetrahedral with $\mathrm{N}-\mathrm{K}(1)-\mathrm{N}$ and $\mathrm{N}-\mathrm{K}(1)-\mathrm{Cm}(1)$ ranging $61.9(1)-65.2(1)^{\circ}$ and $128.9-152.9^{\circ}$, respectively. While the potassium-nitrogen bond lengths for the nitrido and $\mathrm{NH}$ imido groups are almost identical $(\mathrm{K}(1)-\mathrm{N}(13) 2.772(4)$ and $\mathrm{K}(1)-\mathrm{N}(23) 2.776(4) \AA$, respectively), those associated with the bulkier trimethylsilylimido ligands are significantly longer $(\mathrm{K}(1)-\mathrm{N}(12) 3.108(4) \AA)$. The steric repulsion of the $\mathrm{SiMe}_{3}$ group might also be responsible of the differences in the potassium-carbon $\left(\mathrm{C}_{5} \mathrm{Me}_{5}\right)$ bond lengths (range 3.000(4)-3.258(4) $\AA$ ), being the shortest distances those with the $\mathrm{C}(13)$ and $\mathrm{C}(14)$ carbon atoms located on the opposite side of the trimethylsilylimido ligand.

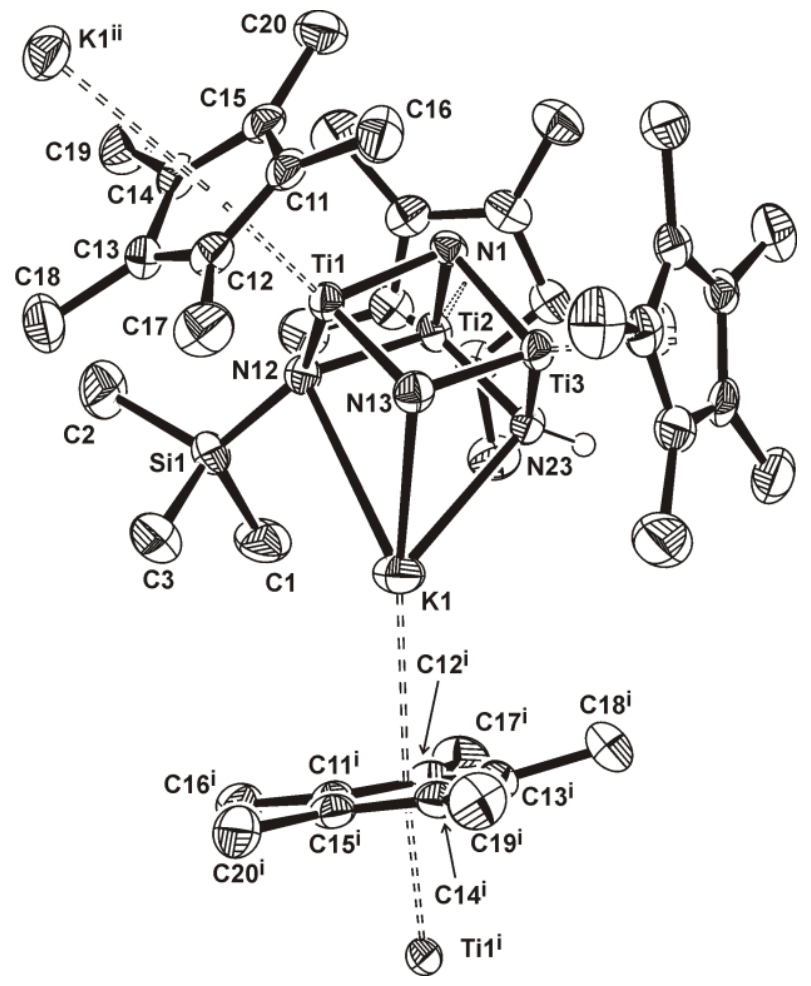

Figure 6. Perspective view of a portion of the polymeric chain of compound $\mathbf{8}$ (thermal ellipsoids at the $50 \%$ probability level). Hydrogen atoms of the pentamethylcyclopentadienyl groups are omitted for clarity. Symmetry code: (i) $-\mathrm{x}, 1 / 2+\mathrm{y},-1 / 2-\mathrm{z} ;$ (ii) $-\mathrm{x},-1 / 2+\mathrm{y},-1 / 2-\mathrm{z}$. 
Table 6. Selected Lengths $(\AA)$ and Angles (deg) for Compound $8 .^{a}$

\begin{tabular}{|c|c|c|c|}
\hline $\mathrm{K}(1)-\mathrm{N}(12)$ & $3.108(4)$ & $\mathrm{K}(1)-\mathrm{N}(13)$ & $2.772(4)$ \\
\hline $\mathrm{K}(1)-\mathrm{N}(23)$ & $2.776(4)$ & $\mathrm{K}(1)-\mathrm{C}(11)^{\mathrm{i}}$ & $3.258(4)$ \\
\hline $\mathrm{K}(1)-\mathrm{C}(12)^{\mathrm{i}}$ & $3.168(4)$ & $\mathrm{K}(1)-\mathrm{C}(13)^{\mathrm{i}}$ & $3.006(4)$ \\
\hline$K(1)-C(14)^{i}$ & $3.000(4)$ & $K(1)-C(15)^{i}$ & $3.171(4)$ \\
\hline $\mathrm{K}(1)-\mathrm{Cm}(1)^{\mathrm{i}}$ & 2.882 & $\operatorname{Ti}(1)-\mathrm{N}(12)$ & $1.980(3)$ \\
\hline $\mathrm{Ti}(1)-\mathrm{N}(13)$ & $1.860(3)$ & $\operatorname{Ti}(1)-\mathrm{N}(1)$ & $1.916(3)$ \\
\hline $\operatorname{Ti}(1)-\operatorname{Cm}(1)^{b}$ & 2.147 & $\operatorname{Ti}(2)-\mathrm{N}(12)$ & $1.961(3)$ \\
\hline $\mathrm{Ti}(2)-\mathrm{N}(23)$ & $1.913(4)$ & $\operatorname{Ti}(2)-\mathrm{N}(1)$ & $1.905(3)$ \\
\hline $\operatorname{Ti}(2)-\operatorname{Cm}(2)^{b}$ & 2.105 & $\operatorname{Ti}(3)-\mathrm{N}(13)$ & $1.883(3)$ \\
\hline $\operatorname{Ti}(3)-\mathrm{N}(23)$ & $1.929(4)$ & $\mathrm{Ti}(3)-\mathrm{N}(1)$ & $1.957(3)$ \\
\hline $\operatorname{Ti}(3)-\operatorname{Cm}(3)^{b}$ & 2.126 & $\mathrm{Si}(1)-\mathrm{N}(12)$ & $1.713(3)$ \\
\hline $\operatorname{Ti}(1) \cdots \operatorname{Ti}(2)$ & $2.805(2)$ & $\operatorname{Ti}(1) \cdots \operatorname{Ti}(3)$ & $2.762(2)$ \\
\hline $\operatorname{Ti}(2) \cdots \operatorname{Ti}(3)$ & $2.804(3)$ & & \\
\hline $\mathrm{N}(12)-\mathrm{K}(1)-\mathrm{N}(13)$ & $62.0(1)$ & $\mathrm{N}(12)-\mathrm{K}(1)-\mathrm{N}(23)$ & $61.9(1)$ \\
\hline $\mathrm{N}(13)-\mathrm{K}(1)-\mathrm{N}(23)$ & $65.2(1)$ & $\mathrm{N}(12)-\mathrm{K}(1)-\mathrm{Cm}(1)^{\mathrm{i}}$ & 143.2 \\
\hline $\mathrm{N}(13)-\mathrm{K}(1)-\mathrm{Cm}(1)^{\mathrm{i}}$ & 152.9 & $\mathrm{~N}(23)-\mathrm{K}(1)-\mathrm{Cm}(1)^{\mathrm{i}}$ & 128.9 \\
\hline $\mathrm{N}(12)-\mathrm{Ti}(1)-\mathrm{N}(13)$ & 104.7(2) & $\mathrm{N}(12)-\operatorname{Ti}(1)-\mathrm{N}(1)$ & $86.5(1)$ \\
\hline $\mathrm{N}(13)-\mathrm{Ti}(1)-\mathrm{N}(1)$ & $87.7(1)$ & $\mathrm{N}(12)-\mathrm{Ti}(2)-\mathrm{N}(23)$ & $103.4(1)$ \\
\hline $\mathrm{N}(12)-\mathrm{Ti}(2)-\mathrm{N}(1)$ & $87.4(1)$ & $\mathrm{N}(23)-\mathrm{Ti}(2)-\mathrm{N}(1)$ & $87.3(2)$ \\
\hline $\mathrm{N}(13)-\mathrm{Ti}(3)-\mathrm{N}(23)$ & 103.3(2) & $\mathrm{N}(13)-\operatorname{Ti}(3)-\mathrm{N}(1)$ & $85.9(1)$ \\
\hline $\mathrm{N}(23)-\mathrm{Ti}(3)-\mathrm{N}(1)$ & $85.4(2)$ & $\mathrm{Ti}(1)-\mathrm{N}(12)-\mathrm{Ti}(2)$ & $90.7(1)$ \\
\hline $\mathrm{Ti}(1)-\mathrm{N}(12)-\mathrm{K}(1)$ & $89.1(1)$ & $\mathrm{Ti}(2)-\mathrm{N}(12)-\mathrm{K}(1)$ & $90.8(1)$ \\
\hline $\operatorname{Ti}(1)-\mathrm{N}(12)-\mathrm{Si}(1)$ & 133.6(2) & $\operatorname{Ti}(2)-\mathrm{N}(12)-\operatorname{Si}(1)$ & $135.3(2)$ \\
\hline $\mathrm{K}(1)-\mathrm{N}(12)-\mathrm{Si}(1)$ & $85.1(1)$ & $\operatorname{Ti}(1)-\mathrm{N}(13)-\mathrm{Ti}(3)$ & $95.1(2)$ \\
\hline $\mathrm{K}(1)-\mathrm{N}(13)-\mathrm{Ti}(1)$ & $102.5(1)$ & $\mathrm{K}(1)-\mathrm{N}(13)-\mathrm{Ti}(3)$ & $92.9(1)$ \\
\hline $\operatorname{Ti}(2)-\mathrm{N}(23)-\operatorname{Ti}(3)$ & $93.7(2)$ & $\mathrm{K}(1)-\mathrm{N}(23)-\mathrm{Ti}(2)$ & $102.6(1)$ \\
\hline $\mathrm{K}(1)-\mathrm{N}(23)-\mathrm{Ti}(3)$ & $91.8(1)$ & $\operatorname{Ti}(1)-\mathrm{N}(1)-\mathrm{Ti}(2)$ & $94.5(1)$ \\
\hline $\operatorname{Ti}(1)-\mathrm{N}(1)-\mathrm{Ti}(3)$ & $91.0(1)$ & $\operatorname{Ti}(2)-\mathrm{N}(1)-\mathrm{Ti}(3)$ & $93.1(2)$ \\
\hline
\end{tabular}

${ }^{a}$ Symmetry code: (i) $-\mathrm{x}, 1 / 2+\mathrm{y},-1 / 2-\mathrm{z} .{ }^{b} \mathrm{Cm}=$ centroid of the $\eta^{5}-\mathrm{C}_{5} \mathrm{Me}_{5}$ groups. 
Addition of 1 equiv of 18 -crown- 6 to a toluene solution of $\mathbf{8}$ led to the immediate precipitation of the well-separated ion pair $\left[\mathrm{K}(18-\right.$ crown-6) $]\left[\mathrm{Ti}_{3}\left(\eta^{5}-\mathrm{C}_{5} \mathrm{Me}_{5}\right)_{3}\left(\mu_{3}-\mathrm{N}\right)(\mu-\mathrm{N})(\mu-\right.$ $\left.\mathrm{NH})\left(\mu-\mathrm{NSiMe}_{3}\right)\right](9)$. This compound was isolated in $80 \%$ yield as a yellow powder, which is only soluble in pyridine- $\mathrm{d}_{5}$ while reacts immediately with chloroform- $\mathrm{d}_{1}$ to give complex 7 and free 18-crown-6 according to NMR spectroscopy. ${ }^{1} \mathrm{H}$ and ${ }^{13} \mathrm{C}\left\{{ }^{1} \mathrm{H}\right\}$ NMR spectra of 9 in pyridine- $\mathrm{d}_{5}$ show resonances for three different $\eta^{5}-\mathrm{C}_{5} \mathrm{Me}_{5}$ ligands in accord with a $C_{1}$ symmetry for the trinuclear titanium anion. In addition, the ${ }^{1} \mathrm{H}$ NMR spectrum of 9 shows a sharp singlet for the methylene groups of one crown ether ligand per anionic fragment. The three resonances for the ipso carbon of the $\eta^{5}-\mathrm{C}_{5} \mathrm{Me}_{5}$ groups $(\delta=114.2,113.3$, and 113.0) in the ${ }^{13} \mathrm{C}\left\{{ }^{1} \mathrm{H}\right\}$ NMR spectrum of 9 are slightly shifted upfield with respect to those found in the spectra of $\mathbf{8}$ in pyridine- $\mathrm{d}_{5}\left(\delta=115.4,114.4\right.$, and 113.3) or benzene- $\mathrm{d}_{6}(\delta=116.6$, 115.9, and 113.9). Most likely the structure of compound $\mathbf{8}$ in those solutions contains a cube-type $\left[\mathrm{KTi}_{3} \mathrm{~N}_{4}\right]$ core with solvent molecules coordinated to the potassium atom as a result of the rupture of the polymeric association determined in the solid-state.

\section{Conclusion}

The imido-nitrido complex $\left[\left\{\mathrm{Ti}\left(\eta^{5}-\mathrm{C}_{5} \mathrm{Me}_{5}\right)(\mu-\mathrm{NH})\right\}_{3}\left(\mu_{3}-\mathrm{N}\right)\right](\mathbf{1})$ reacts with 1 equiv of electrophilic reagents ROTf $(\mathrm{R}=\mathrm{H}, \mathrm{Me})$ through selective protonation or methylation at one imido nitrogen to give $\left[\mathrm{Ti}_{3}\left(\eta^{5}-\mathrm{C}_{5} \mathrm{Me}_{5}\right)_{3}\left(\mu_{3}-\mathrm{N}\right)(\mu-\mathrm{NH})_{2}(\mu-\mathrm{NHR})(\mathrm{OTf})\right]$, with coordination of the triflato ligand to the opposite titanium atom of the resultant amido NHR. In those complexes, the triflato is hydrogen-bonded to the NHR group and assists the proton exchange between amido NHR and imido NH ligands. The larger trimethylsilyl fragment of $\mathrm{Me}_{3} \mathrm{SiOTf}$ attacks the same nitrogen of $\mathbf{1}$ but produces a complex $\left[\mathrm{Ti}_{3}\left(\eta^{5}-\right.\right.$ 
$\left.\left.\mathrm{C}_{5} \mathrm{Me}_{5}\right)_{3}\left(\mu_{3}-\mathrm{N}\right)(\mu-\mathrm{NH})_{2}\left(\mu-\mathrm{NHSiMe}_{3}\right)\right][\mathrm{OTf}]$ with the triflate anion not coordinated to the metals. Deprotonation of this ionic compound with $\left[\mathrm{K}\left\{\mathrm{N}\left(\mathrm{SiMe}_{3}\right)_{2}\right\}\right]$ occurs at the imido $\mathrm{NH}$ ligands rather than involving the $\mathrm{NHSiMe}_{3}$ group, and the resultant molecular complex $\left[\mathrm{Ti}_{3}\left(\eta^{5}-\mathrm{C}_{5} \mathrm{Me}_{5}\right)_{3}\left(\mu_{3}-\mathrm{N}\right)(\mu-\mathrm{N})(\mu-\mathrm{NH})\left(\mu-\mathrm{NHSiMe}_{3}\right)\right]$ readily rearranges to the trimethylsilylimido derivative $\left[\mathrm{Ti}_{3}\left(\eta^{5}-\mathrm{C}_{5} \mathrm{Me}_{5}\right)_{3}\left(\mu_{3}-\mathrm{N}\right)(\mu-\mathrm{NH})_{2}\left(\mu-\mathrm{NSiMe}_{3}\right)\right]$. The latter can be further deprotonated with $\left[\mathrm{K}\left\{\mathrm{N}\left(\mathrm{SiMe}_{3}\right)_{2}\right\}\right]$ to give a potassium complex $\left[\mathrm{K}\left\{\left(\mu_{3}-\mathrm{N}\right)\left(\mu_{3}-\right.\right.\right.$ $\left.\left.\mathrm{NH})\left(\mu_{3}-\mathrm{NSiMe}_{3}\right) \mathrm{Ti}_{3}\left(\eta^{5}-\mathrm{C}_{5} \mathrm{Me}_{5}\right)_{3}\left(\mu_{3}-\mathrm{N}\right)\right\}\right]$ and upon addition of 18 -crown-6 leads to the wellseparated ion-pair $\left[\mathrm{K}\left(18\right.\right.$-crown-6)][Ti $\left.3{ }_{3}\left(\eta^{5}-\mathrm{C}_{5} \mathrm{Me}_{5}\right)_{3}\left(\mu_{3}-\mathrm{N}\right)(\mu-\mathrm{N})(\mu-\mathrm{NH})\left(\mu-\mathrm{NSiMe}_{3}\right)\right]$. The treatment of 1 with one equivalent of electrophiles and subsequent reactions on the resultant products described here have shown the possibility of preparing a series of cationic, neutral, or anionic trinuclear titanium complexes bearing bridging amido, imido and nitrido functionalities. Several of these species undergo interesting rearrangement reactions involving proton exchange between the nitrogen ligands. Current work is exploring the reactivity of $\mathbf{1}$ with a variety of electrophiles in higher molar ratios.

Acknowledgments. We are grateful to the Spanish MICINN (CTQ200800061/BQU), Comunidad de Madrid and the Universidad de Alcalá (CCG10-UAH/PPQ5935), and the Factoría de Cristalización (CONSOLIDER-INGENIO 2010 CSD200600015) for financial support of this research. J.C. and M.G.-M. thank the MEC and UAH for doctoral fellowships.

Supporting Information Available. Kinetic data and analyses for the dynamic NMR spectroscopy study for compounds $\mathbf{2}$ and $\mathbf{3}$, and the crystal structure of complex $\mathbf{5}$ showing 
the hydrogen bonds between ions (PDF). X-ray crystallographic files in CIF format for complexes 2, 5, 6 and 8. This material is available free of charge via the Internet at http://pubs.acs.org.

\section{Notes}

The authors declare no competing financial interest. 


\section{References}

(1) (a) Nugent, W. A.; Mayer, J. M. Metal-Ligand Multiple Bonds; John Wiley \& Sons: New York, 1988. (b) Eikey, R. A.; Abu-Omar, M. M. Coord. Chem. Rev. 2003, 243, 83-124. (c)

Berry, J. F. Comments Inorg. Chem. 2009, 30, 28-66.

(2) (a) Nugent, W. A.; McKinney, R. J.; Kasowski, R. V.; Van-Catledge, F. A. Inorg. Chim. Acta 1982, 65, L91-L93. (b) Romo, S.; Antonova, N. S.; Carbó, J. J.; Poblet, J.-M. Dalton Trans. 2008, 5166-5172.

(3) Hedegård, E. D.; Bendix, J.; Sauer, S. P. A. J. Mol. Struct.: THEOCHEM 2009, 913, 1-7.

(4) For selected examples of the reaction of nitrido complexes with nucleophiles, see: (a) Crevier, T. J.; Bennett, B. K.; Soper, J. D.; Bowman, J. A.; Dehestani, A.; Hrovat, D. A.; Lovell, S.; Kaminsky, W.; Mayer, J. M. J. Am. Chem. Soc. 2001, 123, 1059-1071. (b) Seymore, S. B.; Brown, S. N. Inorg. Chem. 2002, 41, 462-469. (c) Bennet, B. K.; Saganic, E.; Lovell, S.; Kaminsky, W.; Samuel, A.; Mayer, J. M. Inorg. Chem. 2003, 42, 4127-4134. (d) Yi, X.-Y.; Lam, T. C. H.; Sau, Y.-K.; Zhang, Q.-F.; Williams, I. D.; Leung, W.-H. Inorg. Chem. 2007, 46, 7193-7198. (e) Yi, X.-Y.; Ng, H.-Y.; Williams, I. D.; Leung, W.-H. Inorg. Chem. 2011, 50, 1161-1163.

(5) For selected examples of the reaction of imido complexes with nucleophiles, see: (a) Shapley, P. A.; Shusta, J. M.; Hunt, J. L. Organometallics 1996, 15, 1622-1629. (b) Kogut, E.; Wiencko, H. L.; Zhang, L.; Cordeau, D. E.; Warren, T. H. J. Am. Chem. Soc. 2005, 127, 11248-11249.

(6) For selected examples of the reaction of nitrido complexes with electrophiles, see: (a) Shapley, P. A.; Own, Z.-Y.; Huffman, J. C. Organometallics 1986, 5, 1269-1271. (b) Marshman, R. W.; Shapley, P. A. J. Am. Chem. Soc. 1990, 112, 8369-8378. (c) Marshman, 
R. W.; Shusta, J. M.; Wilson, S. R.; Shapley, P. A. Organometallics, 1991, 10, 1671-1676.

(d) Sellmann, D.; Wemple, M. W.; Donaubauer, W.; Heinemann, F. W. Inorg. Chem. 1997, 36, 1397-1402. (e) Leung, W.-H.; Chan, E. Y. Y.; Lai, T. C. Y.; Wong, W.-T. J. Chem. Soc., Dalton Trans. 2000, 51-56. (f) Abram, U.; Voigt, A.; Kirmse, R. Polyhedron 2000, 19, 1741-1748. (g) Sceats, E. L.; Figueroa, J. S.; Cummins, C. C.; Loening, N. M.; Van der Wel, P.; Griffin, R. G. Polyhedron 2004, 23, 2751-2768. (h) Lutz, C. M.; Wilson, S. R.; Shapley, P. A. Organometallics 2005, 24, 3350-3353. (i) Sarkar, S.; Abboud, K. A.; Veige, A. S. J. Am. Chem. Soc. 2008, 130, 16128-16129. (j) Walstrom, A.; Fan, H.; Pink, M.; Caulton, K. G. Inorg. Chim. Acta 2010, 363, 633-636. (k) Curley, J. J.; Cozzolino, A. F.; Cummins, C. C. Dalton Trans. 2011, 40, 2429-2432.

(7) For selected examples of the reaction of imido complexes with electrophiles, see: (a) Chiu, K. W.; Wong, W.-K.; Wilkinson, G.; Galas, A. M. R.; Hursthouse, M. B. Polyhedron 1982, 1, 31-36. (b) Powell, K. R.; Pérez, P. J.; Luan, L.; Feng, S. G.; White, P. S.; Brookhart, M.; Templeton, J. L. Organometallics 1994, 13, 1851-1864. (c) Gountchev, T. I.; Tilley, T. D. J. Am. Chem. Soc. 1997, 119, 12831-12841. (d) Tonzetich, Z. J.; Schrock, R. R.; Müller, P. Organometallics 2006, 25, 4301-4306.

(8) For accounts on the types of imido complexes, see: (a) Nugent, W. A.; Haymore, B. L. Coord. Chem. Rev. 1980, 31, 123-175. (b) Wigley, D. E. Progr. Inorg. Chem. 1994, 42, $239-482$.

(9) For reviews on polynuclear nitrido complexes, see: (a) Dehnicke, K.; Strähle, J. Angew. Chem., Int. Ed. Engl. 1981, 20, 413-426. (b) Dehnicke, K.; Strähle, J. Angew. Chem., Int. Ed. Engl. 1992, 31, 955-978. (c) Dehnicke, K.; Weller, F.; Strähle, J. Chem. Soc. Rev. 2001, 30, 125-135. 
(10) Morello, L.; Yu, P.; Carmichael, C. D.; Patrick, B. O.; Fryzuk, M. D. J. Am. Chem. Soc. 2005, $127,12796-12797$.

(11) (a) MacKay, B. A.; Munha, R. F.; Fryzuk, M. D. J. Am. Chem. Soc. 2006, 128, 9472-9483. (b) Hirotsu, M.; Fontaine, P. P.; Epshteyn, A.; Zavalij, P. Y.; Sita, L. R. J. Am. Chem. Soc. 2007, 129, 9284-9285. (c) Akagi, F.; Matsuo, T.; Kawaguchi, H. Angew. Chem., Int. Ed. 2007, 46, 8778-8781. (d) Nikiforov, G. B.; Vidyaratne, I.; Gambarotta, S.; Korobkov, I. Angew. Chem., Int. Ed. 2009, 48, 7415-7419.

(12) (a) Roesky, H. W.; Bai, Y.; Noltemeyer, M. Angew. Chem., Int. Ed. Engl. 1989, 28, 754755. (b) Abarca, A.; Gómez-Sal, P.; Martín, A.; Mena, M.; Poblet, J.-M.; Yélamos, C. Inorg. Chem. 2000, 39, 642-651.

(13) (a) Abarca, A.; Martín, A.; Mena, M.; Yélamos, C. Angew. Chem., Int. Ed. 2000, 39, 34603463. (b) Freitag, K.; Gracia, J.; Martín, A.; Mena, M.; Poblet, J.-M.; Sarasa, J. P.; Yélamos, C. Chem. Eur. J. 2001, 7, 3644-3651. (c) García-Castro, M.; Gracia, J.; Martín, A.; Mena, M.; Poblet, J.-M.; Sarasa, J. P.; Yélamos, C. Chem. Eur. J. 2005, 11, 1030-1041. (d) García-Castro, M.; Martín, A.; Mena, M.; Yélamos, C. Organometallics 2007, 26, 408416. (e) Martínez-Espada, N.; Mena, M.; Mosquera, M. E. G.; Pérez-Redondo, A.; Yélamos, C. Organometallics 2010, 29, 6732-6738. (f) Caballo, J.; García-Castro, M.; Martín, A.; Mena, M.; Pérez-Redondo, A.; Yélamos, C. Inorg. Chem. 2011, 50, 6798-6808.

(14) Carbó, J. J.; Martínez-Espada, N.; Mena, M.; Mosquera, M. E. G.; Poblet, J.-M.; Yélamos, C. Chem. Eur. J. 2009, 15, 11619-11631.

(15) Carbó, J. J.; Martín, A.; Mena, M.; Pérez-Redondo, A.; Poblet, J.-M.; Yélamos, C. Angew. Chem., Int. Ed. 2007, 46, 3095-3098. 
(16) Caballo, J.; González-Moreiras, M.; Mena, M.; Pérez-Redondo, A.; Yélamos, C. Dalton Trans. 2012, 41, 6069-6071.

(17) García-Castro, M.; Martín, A.; Mena, M.; Pérez-Redondo, A.; Yélamos, C. Chem. Eur. J. 2001, 7, 647-651.

(18) Farrugia, L. J. J. Appl. Crystallogr. 1999, 32, 837-838.

(19) Sheldrick, G. M. Acta Crystallogr., Sect. A 2008, 64, 112-122.

(20) (a) Duan, Z.; Verkade, J. G. Inorg. Chem. 1996, 35, 5325-5327. (b) Carmalt, C. J.; Mileham, J. D.; White, A. J. P.; Williams, D. J. New. J. Chem. 2000, 24, 929-930.

(21) (a) Schubart, M.; O’Dwyer, L.; Gade, L. H.; Li, W.-S.; McPartlin, M. Inorg. Chem. 1994, 33, 3893-3898. (b) Ngo, S. C.; Toscano, P. J.; Welch, J. T. Helv. Chim. Acta 2002, 85, 3366-3382. (c) Kessler, M.; Hansen, S.; Hollmann, D.; Klahn, M.; Beweries, T.; Spannenberg, A.; Brückner, A.; Rosenthal, U. Eur. J. Inorg. Chem. 2011, 627-631. (d) Davidson, M. G.; Johnson, A. L. Eur. J. Inorg. Chem. 2011, 5151-5159.

(22) (a) Jeffrey, G. A. An Introduction to Hydrogen Bonding; Oxford University Press: New York, 1997. (b) Steiner, T. Angew. Chem., Int. Ed. 2002, 41, 48-76.

(23) Nakamoto, K. Infrared and Raman Spectra of Inorganic and Coordination Compounds, 5th ed.; Wiley: New York, 1997.

(24) (a) Lawrance, G. A. Chem. Rev. 1986, 86, 17-33. (b) Johnston, D. H.; Shriver, D. F. Inorg. Chem. 1993, 32, 1045-1047. (c) Huang, W.; Frech, R.; Wheeler, R. A. J. Phys. Chem. 1994, 98, 100-110.

(25) (a) Männle, F.; Limbach, H.-H. Angew. Chem., Int. Ed. Engl. 1996, 35, 441-442. (b) Limbach, H.-H.; Männle, F.; Detering, C.; Denisov, G. S. Chem. Phys. 2005, 319, 69-92. 
(26) (a) Lee, K. E.; Gladysz, J. A. Polyhedron 1988, 7, 2209-2211. (b) Straus, D. A.; Zhang, C.; Quimbita, G. E.; Grumbine, S. D.; Heyn, R. H.; Tilley, T. D.; Rheingold, A. L.; Geib, S. J. J. Am. Chem. Soc. 1990, 112, 2673-2681. (c) Straus, D. A.; Grumbine, S. D.; Tilley, T. D.; J. Am. Chem. Soc. 1990, 112, 7801-7802. (d) Burns, R. M.; Hubbard, J. L. J. Am. Chem. Soc. 1994, 116, 9514-9520. (e) Hayashida, T.; Kondo, H.; Terasawa, J.; Kirchner, K.; Sunada, Y.; Nagashima, H. J. Organomet. Chem. 2007, 692, 382-394.

(27) (a) Sandström, J. Dynamic NMR Spectroscopy; Academic Press: London, 1992. (b) gNMR, version 4; Cherwell Scientific Publishing: Oxford, U.K., 1997.

(28) (a) Mann, B. E. Non-Rigidity in Organometallic Compounds, in Comprehensive Organometallic Chemistry; Geoffrey, W.; Gordon, F.; Stone, A.; Abel, E. W., Eds.; Pergamon: Oxford, U.K., 1982, Vol. 20, pp 89-171. (b) Faller, J. W. Stereochemical Nonrigidity of Organometallic Complexes; in Encyclopedia of Inorganic Chemistry, 2nd ed.; King, R. B., Ed.; John Wiley \& Sons: Chichester, U.K., 2005, Vol. 8, pp 5270-5303.

(29) (a) Caldin, E. F.; Mateo, S. J. Chem. Soc., Faraday Trans. 1 1975, 71, 1876-1904. (b) Scherer, G.; Limbach, H.-H. J. Am. Chem. Soc. 1994, 116, 1230-1239.

(30) Martín, A.; Mena, M.; Pérez-Redondo, A.; Yélamos, C. Inorg. Chem. 2004, 43, 2491-2498. 